\title{
Judicial Review of Military
}

\section{Administrative Discharges}

\author{
Christopher H. Lunding*
}

On April 20, 1968, Private Andrew Stapp, a draftee, had only twenty days yet to serve in the United States Army. His service record was creditable: During nearly two years of duty at Fort Jackson, South Carolina, and Fort Sill, Oklahoma, he had consistently received "good" and "excellent" conduct and efficiency ratings. ${ }^{1}$ But unlike more than 90 percent of the men and women mustered out of the armed forces in recent years, ${ }^{2}$ Stapp did not receive an Honorable Discharge. Rather, as a result of associating with groups considered subversive, he was awarded a discharge labeled "Undesirable."3

In a subsequent action in a civilian federal court, Stapp succeeded in having his discharge reclassified "Honorable" on the ground that he had been charged with nothing more "undesirable" than Marxist beliefs and associations. ${ }^{4}$ But had Private Stapp not been willing to go to the effort of seeking judicial relief, his leftist beliefs and associations would have cost him dearly.

Recipients of "Undesirable" discharges are considerably disadvantaged upon their return to civilian life. Yet such derogatory discharges are meted out by the services in a manner which does not adequately safeguard rights afforded servicemen by regulations, statutes, and the Constitution. This article argues that the administrative discharge system violates developing standards of due process. In addition, it examines the availability of judicial relief within the framework of the present system and considers the jurisdiction of courts to review military discharge practices.

\section{The Administrative Discharge System}

The "Undesirable Discharge" is one of five types of discharge which an enlisted member of the United States military services may receive

- A.B. 1968, Harvard University; J.D. 1971, Yale University; member of the New York and Florida Bars.

1. Stapp v. Resor, 314 F. Supp. 475,477 (S.D.N.Y. 1970).

2. Letter from Office of Ass't Sec'y of Defense, Oct. 27, 1972, on file with the Yale Law Journal.

3. Stapp v. Resor, 314 F. Supp. 475 (S.D.N.Y. 1970).

4. Id. 
upon separation. ${ }^{5}$ Two, the Dishonorable Discharge and the Bad Conduct Discharge, are expressly punitive and can be awarded only upon conviction or plea of guilty in a court-martial proceeding. ${ }^{6} \mathrm{~A}$ recipient of either often loses all veterans' benefits ${ }^{7}$ and is likely to encounter substantial difficulties in obtaining civilian employment. ${ }^{s}$

The other three types of discharge-Honorable, General, and Undesirable-are awarded administratively. General and Undesirable Discharges are given to only a small percentage of service members. ${ }^{9} \mathrm{Al}$ though neither is expressly punitive, the receipt of either can prove a considerable liability to a veteran in civilian life. According to the Air Force the General Discharge creates "a definite disadvantage to

5. The five types of discharge are intended to reflect the character of an individual's service. The discharge categories-Honorable, General, Undesirable, Bad Conduct, and Dishonorable-complement four official denominations of character of service: Honorable, Under Honorable Conditions, Under Other Than Honorable Conditions, and Dishonorable. The Honorable and Dishonorable Discharges correspond to the Honorable and Dishonorable character of service designations; the General Discharge corresponds to the Under Honorable Conditions designation; and the Bad Conduct and Undesirable Discharges correspond to the Under Other Than Honorable Conditions designation. The character of service appears in the service record, Form DD 214 , given to the serviceman at separation. The type of discharge appears only in the discharge certificate, a separate document. The four denominations of character of service are set forth in Army Regulation (AR) 635-5, Personnel Separations-Separation Documents $72-22$ (1972). The five types of discharge appear in AR 635-200, Personnel Separations-Enlisted Personnel 1 1-5 (1966, current through Change 39 of Nov. 23, 1972). The regulations of the other services are similar.

6. See Manual for Courts-Martial, United States 9 ( $76 \mathrm{a}(3),(4), 127 \mathrm{c}$ (rev. ed. 1969) [hereinafter cited as MCM]. Court-martial proceedings which may lead to a punitive discharge must be carried out under the statutory gtidelines of the Uniform Code of Mílitary Justice [hereinafter cited as UCMJ], 10 U.S.C. $\$ \$ 801-940$ (1970). A court. martial may not order a derogatory administrative discharge as punishment. See, e.g. United States v. Phipps, 12 U.S.C.M.A. 14, 30 C.M.R. 14 (1960), Punitive discharges are rarely given. Since 1963 no more than .5 percent of enlisted personnel discharged in any year have received either type of punitive discharge. Letter from Office of Ass't Sec'y of Defense, supra note 2.

7. Under 38 U.S.C. $\$ 101(2)(1970)$ and 38 C.F.R. $\$ 3.12(a)$ (1972), a discharge under Dishonorable Conditions bars all veterans' benefits. A Bad Conduct Discharge ordered by a general court-martial also bars benefits automatically. 38 U.S.C. $\$ 3103$ (1970), 38 C.F.R. $\$ 3.12$ (c)(2) (1972). A Bad Conduct Discharge awarded by a special court-martial bars benefits only if awarded for the reasons contained in 38 U.S.C. $\$ 3103$ (1970) and 38 C.F.R. $\$ \$ 3.12$ (c), (d) (1972). For the difference between the jurisdiction of general and special courts-martial, see 10 U.S.C. $\$ \$ 818,819$ (1970). For a discussion of the discretion exercised by the Veterans' Administration in awarding benefits to persons receiving discharges under "conditions other than dishonorable" but less than "honorable" (i.e., Bad Conduct and Undesirable Discharges, which are awarded under "conditions other than honorable"), see generally Joint Hearings on Drug Addiction and Abuse Among Military Veterans Before the Subcomm. on Health and Hospitals of the Senate Comm. on Veterans Affairs and the Subcomm. on Alcoholism and Narcotics of the Senate Comm. on Labor and Public Welfare, 92d Cong., 1st Sess., pt. 1, at 143-46 (1971).

8. See Jones, The Gravity of Administrative Discharges: $A$ Legal and Empirical Evaluation, 59 MrL. L. RIv. 1, 17-25 (1973).

9. In recent years (fiscal 1966-fiscal 1970), they totaled less than five percent of all enlisted discharges awarded. In fiscal 1971, however, General and Undesirable Discharges together constituted 6.65 percent of such discharges awarded. For fiscal 1972, that figurc jumped to 9.36 percent. Letter from Office of Ass't Sec'y of Defense, supra note 2. 
[a veteran] seeking civilian employment." 10 Courts have found the General Discharge to constitute "a stigma of tremendous impact which [has] a lifelong effect," 11 and a recent statistical study supports these findings. ${ }^{12}$

Receipt of an Undesirable Discharge, the type awarded Private Stapp, can be even more damaging. Closely resembling the punitive discharges, ${ }^{13}$ the Undesirable Discharge usually renders its recipient ineligible for veterans' benefits accruing from his current term of service $^{14}$ and effectively bars him from employment with the federal

10. Air Force Manual (AFM) 39-12, Separation for Unsuitability, Unfitness, Misconduct, Resignation, or Request for Discharge for the Good of the Service and Procedures for the Rehabilitation Program 1-22(a) (1966, current through Change 6 of May 18, 1972). The Army recognizes that an individual issued a General Discharge "may expect to encounter substantial prejudice in civilian life." AR 635-212, Discharge, Unfitness and Unsuitability, figure 1 (1966, current through Change 12 of December 3 , 1971). The prejudicial effect of a General Discharge on employment opportunities is graphically illustrated by the following letter to the Navy:

I want my case to be reviewed, because I want an Honorable Discharge. Can't get a good job with Gen. Discharge. I would like to work for the government, but I can't, because my discharge isn't good enough to work for the government. All I want is a chance to start my career. I have been going out and looking for work and they would ask me what kind of discharge I got, when I tell them, they say they got no openinings [sic]. I have been out of a job for months because of my discharge. Please review it.

Bureau of Naval Personnel Instruction 1626.18, Unauthorized Absence and related problems, Enclosure 1, at 3 (1969, Current through Change 2 of Feb. 28, 1972) (emphasis in original).

11. Unglesby v. Zimny, 250 F. Supp. 714,717 (N.D. Cal. 1965). See Crawford v. Davis, 249 F. Supp. 943, 953 (E.D. Pa.), cert. denied, 383 U.S. 921 (1966) (General Discharge issued on the basis of homosexuality "will adversely stigmatize the plaintiff for the remainder of his life, and he would have difficulty in getting employment with most reputable companies"); Sofranoff v. United States, $165 \mathrm{Ct}$. Cl. 470, 478 (1964) (General Discharge stigmatizes the recipient); Murray v. United States, 154 Ct. Cl. 185, 188 (196I) (General Discharge under honorable conditions carries stigma). But see Ives v. Franke, 27I F.2d 469, 471 (D.C. Cir. I959), cert. denied, 361 U.S. 965 (1960) ("there is no connotation of dishonor in a general discharge which expressly recites that it is 'under honorable conditions." "); Denton v. Seamans, 315 F. Supp. 279, 282 (N.D. Cal. 1970) (difficult to conceive that General Discharge Under Honorable Conditions could be considered stigmatizing) (dictum); Grant v. United States, 162 Ct. Cl. 600, 609 (I963) (General Discharge does not deprive recipient of any "inherent rights").

12. Approximately eight percent of businesses, colleges, unions, and professional examiners recently polled in a national survey would automatically reject a recipient of a General Discharge and fifty-one percent would be influenced by such a discharge. Jones, supra note 8 , at 23.

13. See Conn v. United States, 376 F.2d 878, 881 (Ct. Cl. 1967) (difference between an Undesirable Discharge and a Dishonorable Discharge often is "one which is either misunderstood or has no connotation whatsoever. To a potential employer, the distinction may betoken no"more than a semantic subtlety."). But cf. Pickell v. Reed, 326 F. Supp. 1086, 1089 (N.D. Cal. 1971), aff'd, 446 F.2d 898 (9th Cir.), cert. denied, 404 U.S. 946 (1971) (Undesirable Discharge, unlike Bad Conduct Discharge, is not punishment).

Both the Undesirable and Bad Conduct Discharges correspond to the Under Other Than Honorable Conditions character of service designation. See note 5 supra. See also Hearings on the Constitutional Rights of Military Personnel Before the Subcomm. on Constitutional Rights of the Senate Comm. on the Judiciary Pursuant to S. Res. 260, 87th Cong., 2d Sess. 188 (1962) [hereinafter cited as 1962 Hearings].

14. Eligibility for benefits is determined by the Veterans' Administration in the same manner as in the case of a Bad Conduct Discharge awarded by a special courtmartial. See note 7 supra. 
and most state governments. ${ }^{1 \tilde{5}}$ It also precludes employment in any nongovernmental position which requires access to classified defense information. ${ }^{16}$ Indeed, the holder of an Undesirable Discharge may find it difficult to find any employment at all. ${ }^{17}$

Despite the onus of a General or Undesirable Discharge, the procedures under which each is issued allow prejudice and mistake to taint, if not displace, the proof process. They allow the imposition of sanctions often equal in severity to those which could be given by court-martial for commission of the same acts, ${ }^{18}$ but without the protections afforded by the Uniform Code of Military Justice (UCMJ) in court-martial proceedings. ${ }^{19}$

15. See, e.g., C. Williams \& M. Weinberg, Homosexuals and The Military 117 (1971).

16. See 32 C.F.R. $\$ 155.5$ (1972), which lists among "criteria for determining cligibility for a [security] clearance" "[a]ny behavior, activities, or associations which tend to show that the individual is not reliable or trustworthy" and "[a]ny criminal, in. famous, dishonest, immoral, or notoriously disgraceful conduct, habitual use of intoxicants to excess, drug addiction, or sexual perversion." Since these criteria closely rcsemble the reasons for which General or Undesirable Discharges may be issucd, it is unlikely that anyone so discharged could obtain a security clearance.

17. Twenty percent of those who replied to the national survey cited in notc 8 supra stated that they would automatically reject the recipient of an Undesirable Dis. charge, while 69 percent would be influenced by such a discharge. Many cascs illustrating the employment difficulties of veterans with Undesirable Discharges may be found in Joint Hearings on Bills to Improve the Administration of Justice in the Armed Services Before the Subcomm. on Constitutional Rights of the Senate Comm. on the Judiciary and a Special Subcomm. of the Senate Comm. an Armed Services, 89th Cong," 2d Sess., pt. 2, at 834-36 (1966) [hereinafter cited as 1966 Hearings].

18. Sometimes the administrative sanction is more severe than the court-martial punishment. For example, indecent exposure can lead to an Undesirable Discharge as unfit/sexually perverse. See p. 38 infra. It cannot, however, result in a punitive discharge upon court-martial conviction. See Table of Maximum Punishments, MCMI, supra note $6,1127 \mathrm{c}$.

19. See, e.g., Kent, Practical Benefits for the Accused-A Case Comparison of the U.S. Civilian and Military Systems of Justice, 9 Duquesne L. Rev. 186 (1970-71); Moyer, Procedural Rights of the Military Accused: Advantages Over a Civilian Defendant, 22 MAIN工 L. REv. 105 (1970); Quinn, Some Comparisons Between Courts-Martial and Civilian Practice, 15 U.C.L.A. L. REv. 1240 (1968).

A frequent criticism of the derogatory administrative discharge system is that it cnables military authorities to evade the due process requirements of the UCMI. The possibility for evasion results from the fact that many of the grounds for an Undesirable Discharge amount to offenses under the UCMI. Sexual perversion, for instance, is a basis for issuance of an Undesirable Discharge. 32 C.F.R. \$ 41.6(i)(2) (1972). Perverse sex practices are also punishable under the UCMJ. Sodomy is a specific violation of Article 125, U.C.M.J., 10 U.S.C. \$ 925 (1970). All other perverse acts violate Article 134, U.C.M.J., 10 U.S.C. $\$ 934$ (1970). Conviction by court-martial for perverse sexual acts can result in a punitive discharge. See Table of Maximum Punishments, MCM, supra note $6,9127(\mathrm{c})$.

Rather than seek a court-martial conviction and a subsequent Dishonorable or Bad Conduct Discharge, service authorities may prefer to utilize the more informal administrative discharge procedures to simply eliminate troublemakers. See Judge Advocate Journal, Bul. No. 27, at 6 (Oct. 1958); United States v. Phipps, 12 U.S.C.M.A. 14, 16, 30 C.M.R. 14, 16 (1960) (Quinn, J., concurring). For prior commentary, most of it critical, of the administrative discharge system, see Custis, Due Process and Military Discharges, 57 A.B.A.J. 875 (1971); Dougherty \& Lynch, The Administrative Discharge: Military Justice?, 33 GEo. WASH. L. REv. 498 (1964); Everett, Military Administrative Discharge-The Pendulum Swings, 1966 Duke L.J. 41 (1966); Jones, Jurisdiction of the Federal Courts to Review the Character of Military Administrative Discharges, 57 Couvm. 
Procedures for awarding the two types of derogatory administrative discharges to enlisted personnel are governed by a 1965 Department of Defense directive. ${ }^{20}$ Pursuant to the directive a General Discharge may be issued for a number of reasons. The service member's military record may be judged inadequate to merit an Honorable Discharge. ${ }^{21}$ His discharge may be for the "Convenience of the Government"22 or for dependency, hardship, minority, or disability. ${ }^{23}$ The service member may be "unsuitable," i.e., he is considered to demonstrate inaptitude, ${ }^{24}$ character and behavior disorders, ${ }^{25}$ apathy, ${ }^{26}$ enuresis, alcoholism, financial irresponsibility, or homosexual tendencies. ${ }^{27}$ Finally, a General Discharge may be awarded for the same reasons for which an Undesirable Discharge could issue..8 The 1965 directive gives members of the services no right to a hearing to challenge the issuance

L. REv. 917 (1957); Lane, Evidence and the Administrative Discharge Board, 55 MILITARY L. REv. 95 (1972); Lynch, The Administrative Discharge: Changes Needed?, 22 MAINE L. REv. 141 (1970); Sherman, Judicial Review of Military Determinations and the Exhaustion of Remedies Requirement, 55 VA. L. REv. 483 (1969); Vaira, Extraordinary Relief of Punitive and Administrative Discharge from the Armed Forces, 7 DUQUESNE L. REv. 384 (1969); Comment, Judicial Review of Army Discharge Procedures, 9 STAN. L. REv. I70 (1956); Note, Discharging the Inactive Reservist for Political Activities Affecting His Security Status, 69 YALE L.J. 474 (1960); 20 STAN. L. REv. 360 (1968).

Over the past thirty years witnesses before four separate congressional hearings have testified that the system for awarding unfavorable administrative discharges is lacking in due process protections. Hearings on H.R. 523 (H.R. 10722) Before Subcomm. No. 3 of the House Comm. on Armed Services, 92d Cong., 1st Sess. (1971) [hereinafter cited as 1971 Hearings]; 1966 Hearings, supra note 17; 1962 Hearings, supra note 13; H.R. REP. No. 1510, 79th Cong., 2d Sess. (1946). Legislative attempts to reform the system have nevertheless proven unsuccessful. Bills introduced within the last ten years, none of which were even reported out of committee, are: S. 2247, H.R. 9918, H.R. 10422, 92d Cong., 1st Sess. (1971); S. 1266, H.R. 943, 91st Cong., Ist Sess. (1969); S. 2009, 90th Cong., lst Sess. (1967); S. 745-762, 89th Cong., Ist Sess. (1965); S. 2002-2019, 88th Cong., 1st Sess. (1963). All the Senate bills were introduced by Senator Sam Ervin of North Carolina who favors extensive revision of the administrative discharge procedures. See Ervin, Military Administrative Discharges: Due Process in the Doldrums, 10 SAN DIEgo L. REv. 9 (1973).

20. Department of Defense (DoD) Directive No. 1332.14 (1965, current through Change 5 of August 13, 1969), 32 C.F.R. Pt. 41 (1972). The statutory authority for administrative discharges derives from 10 U.S.C. $\$ 1169$ (1970), which provides that administrative discharge of regular enlisted personnel before expiration of term of service can be accomplished only "as prescribed by the Secretary concerned" or "as otherwise provided by law," and 5 U.S.C. $\$ 301$ (1970), which gives the "head of [a] . . military department" authority to issue regulations generally for "the conduct of its employees." Other statutes govern administrative discharge of certain officers. See, e.g., 10 U.S.C. $\$ \$ 3781-3787,3791-3797$ (1970). These procedures are not significantly fairer than those for enlisted personnel. See note 42 infra. For a critique of the present regulatory system, see Lynch, supra note 19.

2I. 32 C.F.R. $\$ 41.5(b)$ (1972).

22. Id. $\$ 41.6(\mathrm{~b})$.

23. Id. $\$ \$ 41.6(\mathrm{~d}),(\mathrm{e}),(\mathrm{f})$.

24. Id. $\$ 41.6(\mathrm{~g})(1)$.

25. Id. $\$ 41.6(\mathrm{~g})(2)$.

26. Id. $\$ 41.6(\mathrm{~g})(3)$.

27. Id. $\$ 41.6(\mathrm{~g})$.

28. Id. $\$$ 4l.6(i), (j). DoD Directive No. 1332.14 specifies that in such cases an Undesirable Discharge should be awarded "unless the particular circumstances in a given case warrant a General or Honorable discharge." 32 C.F.R. $\$ 41.7(c)(2)$ (1972). 
of a General Discharge, except in the case of an unsuitability discharge where the serviceman has eight or more years of continuous active military service. ${ }^{20}$

The second and more serious type of derogatory administrative separation, the Undesirable Discharge, may be awarded for any of four reasons. ${ }^{30}$ The first, resignation in lieu of court-martial, resembles plea bargaining but without the supervision and protection in the acceptance of pleas provided by a military judge under the UCMJ. ${ }^{31}$ The second, unfitness, encompasses a variety of quasi-criminal actions, such as drug abuse, sexual perversion, and frequent difficulties with civil or military authorities. ${ }^{32}$ The third category, misconduct, includes civil conviction for a crime carrying more than a one-year maximum sentence or involving moral turpitude, fraudulent enlistment, and unauthorized absence for one year or more. The fourth, security, covers activities ranging from disclosure of secret data to behavior "which tend[s] to show that the member is not reliable or trustworthy." 33

A serviceman threatened with an Undesirable Discharge under the last three categories-unfitness, misconduct, and security-has the right to a predischarge hearing before an administrative discharge board. ${ }^{34}$

29. Only the Navy and Marine Corps strictly adhere to the directive. The Army requires that a hearing be granted in all cases which could lead to $a$ discharge for unsuitability. AR 635-212 \&9 6, 10. The Air Force uses a hybrid system, tempering the eight year cut-off with exceptions when certain rank is attained and for other reasons. AFM 39-12 I9 2-6, 2-8. In all cases, however, ex-servicemen may challenge discharges issued to them before two sets of military administrative tribunals, See pp. 41.42 infra.

30. DoD Directive No. 1332.14 (1965, current through Change 5 of August 13, 1969), 32 C.F.R. Pt. 41 (1972).

3I. When a guilty plea is accepted, the elements of the charged offense must be explained to the accused and the military judge must be satisfied "not only that the accused understands the meaning and effect of his plea and admits the allegations to which he has pleaded guilty but also that he is voluntarily pleading guilty because he is convinced that he is in fact guilty." MCM, supra note 6, $970(\mathrm{~b})$. See, e.g., United States v. Burton, 21 U.S.C.M.A. 112, 44 G.M.R. 166 (1971); United States v. Care, 18 U.S.C.M.A. 535, 40 C.M.R. 247 (1969). These protections are not required when an accuscd is allowed to resign for the good of the service.

32. 32 C.F.R. \& 41.6(i) (1972). The other reasons for discharge for unfitncss are shirking, a pattern showing a dishonorable failure to pay just debts, a pattern showing dishonorable failure to contribute adequate support to dependents, and unsanitary habits, a euphemism for repeated venereal disease infections. Undesirable Discharge for contraction of venereal disease violates DoD policy against taking " $[\mathrm{p}]$ unitive measures, whether direct or indirect, whether administrative or ostensibly imposed for public health reasons" against service members who contract such diseases. TB MED 230, NAVMED P-5052-11A, AFP 161-1-12, Treatment and Management of Venereal Disease If 2 (1965) (Joint publication of Army, Navy and Air Force).

33. DoD Directive No. 5210.9, Military Personnel Security Program, Art. VIII, $\S(c)(3)(e)$ (1956, current through Change 3 of July 12, 1965). Section (c)(3) contains the specific criteria for security discharge.

34. 32 C.F.R. $\$ 41.7($ d)(1)(i) (1972). The Board can recommend either retention of the serviceman or the issuance of an Undesirable, General or even Honorable Discharge. Id. $\$ \S 41.8(\mathrm{~b})(1)$, (2). When an Undesirable Discharge is issued as the result of resignation 
Deficiencies in the rules governing such hearings, however, render them less than adequate safeguards of the serviceman's rights.

The hearing takes place before a board of three officers, none of whom need have legal training or expertise. ${ }^{35}$ The respondent is entitled to military counsel, ${ }^{36}$ but this requirement may be of little avail, since the hearing board is not bound by rules of evidence. ${ }^{37}$ In addition, the board cannot compel witnesses to testify before it, ${ }^{38}$ necessitating frequent reliance on written statements. ${ }^{39}$ Thus the respondent often has no chance to confront or cross-examine persons testifying against him. In some situations, in fact, the board may be briefed on the government's position before the hearing ${ }^{40}$ and may receive secret testimony never made available to the serviceman. ${ }^{41} \mathrm{~A}$ further deficiency of some hearing procedures is that the Government is not required to bear the burden of proof. ${ }^{42}$ After the hearing the board's

in lieu of court-martial, the serviceman need not be given a predischarge hearing if, having had the opportunity to consult with counsel, the serviceman certifies in writing that he understands the consequences of his action. Id. $\$ 41.7(d)(5)$.

35. Id. $\$ 41.8($ a). DoD Directive No. 1332.14 specifies only that members of such boards must be "experienced."

36. 32 C.F.R. $\$ 41.8$ (c)(1) (1972). Only the Air Force requires that this counsel be a lawyer, AFM 39-12 1 1.4(f). The other services allow nonlawyers to represent respondents when an "appropriate authority" certifies that a lawyer is not available and sets forth the qualifications of the substituted nonlawyer counsel. This practice is authorized by DoD Directive No. 1332.14, 32 C.F.R. $\$ 41.3(\mathrm{k})$ (1972).

37. See 32 C.F.R. $\$ 41.8(\mathrm{~b})$ (1972). The Air Force, which is the most scrupulous of the services in setting evidentiary standards, provides only that "general observance of the essence" of the rules of evidence will "promote orderly procedure." Absent from its list of the "essence" are the rules requiring determination of the voluntariness of a confession and independent evidence of guilt and barring use of evidence obtained through illegal search and seizure. Air Force Regulation (AFR) 11-1, Boards of Officers For Conducting Investigations If 9 (1953, current through Change Il-1A of May 28, 1963), 32 C.F.R. $\$ 866.9$ (b) (1972). Even this diluted "essence" need not be observed and an Air Force board may consider ex parte affidavits and unsworn writings. $I d$. $\S 866.9(\mathrm{a})$.

38. 32 C.F.R. $\$ 41.8$ (c)(3) (1972). Although no specific statute gives subpoena power to administrative discharge boards, the Court of Inquiry Article of the UCMJ could be used for this purpose. Article 135, U.C.M.J., 10 U.S.C. $\$ 935(f)$ (1970). See 32 C.F.R. $\$ 719.417$ et seq. (1972) (Navy regulation). When asked why resort to this provision was not made for cases in which attendance of witnesses would be beneficial, the Navy replied only that its use would have "the inevitable result in many routine cases of obfuscating the true issue in a welter of procedure." 1962 Hearings, supra note 13, at 922.

39. See Statement of Maj. Gen. Leo E. Benade, Deputy Ass't Sec'y of Defense for Military Personnel Policy, 1971 Hearings, supra note 19, at 5854.

40. See Secretary of the Navy Instruction (Sec. Nav. Inst.) $5521.6 \mathrm{~A}$, Navy and Marine Corps Military Personnel Security Program \& III(B)(1)(a) (1957, current through Change 5 of Nov. 6, 1965).

41. See id. \$III(B)(8)(c); AR 604-10, Military Personnel Security Program \$( 6-5(a)(2), 6-6(d) (1969); AFR 35-62, Military Personnel Security Program đ 12(c) (1965).

42. DoD Directive No. 1332.14, supra note 20, does not require the Government to bear the burden of proof. In cases involving enlisted personnel the Marine Corps specifics that the Government bears the burden of proof by a preponderance of the evidence. Marine Corps Separation and Retirement Manual [hereinafter cited as MarCorSep Man] fN 6024(3)(s), (t) (1968, current through Change 8 of 1972), 32 G.F.R. $\$ \$ 730.73(c)(19),(20)$ (1972). The enlisted discharge regulations of the other services are generally silent on the subject, although the Navy regulation governing discharge 
findings and recommendations need not be disclosed to the serviceman, ${ }^{43}$ who thus may not discover factual errors in them. Finally, the hearing rules fail to adequately insulate the procedure from command influence. Thus, an officer of sufficient rank may not only institute derogatory discharge proceedings but also pick members of the hearing board. 44

After the board has made its findings and recommendations, they are reviewed by the "Discharge Authority," an official authorized to take final action with respect to specified types of discharges. ${ }^{45}$ This official may direct issuance of the type of discharge recommended by the board ${ }^{46}$ or he may order a more favorable discharge; ${ }^{47}$ he cannot, however, order a less favorable discharge than that recommended. ${ }^{48}$ However, even if the board has recommended retention of the serviceman, the Discharge Authority may order an Honorable or General Discharge. ${ }^{49}$ Finally, the Discharge Authority may suspend execution of an administrative discharge to afford a serviceman time to "demonstrate successful rehabilitation" ${ }^{50}$ or he may disregard a discharge recommendation altogether and order retention of the serviceman. ${ }^{51}$

After his separation from the armed forces has been ordered and executed, ${ }^{52}$ an ex-serviceman may apply for relief from errors leading to his administrative discharge before two types of administrative re-

for security reasons specifies that "[n]o burden of proof whatsoever shall be borne by the Government." Sec. Nav. Inst. $5521.6 \mathrm{~A}$, App. 3, $\mathrm{i}$. The Air Force requires a regular officer being processed for derogatory administrative discharge to bear the burden of showing that he should be retained, AFR 36-2, Officer Personnel, Administrative Discharge Procedures (Unfitness, Unacceptable Conduct, or In The Interest of National Security), If 24(a) (1971, current through Change I of March 31, 1972); AFR 36-3, Officer Personnel, Administrative Discharge Procedures (Substandard Performance of Duty), I 24(a) (1971, current through Change 1 of March 31, 1972). See 10 U.S.C. $\$ \S 8781-8783,8791-8793$ (1970). AFM 36-18, Guidance Manual for Boards of Inquiry $\mid$ I $3-8(\mathrm{a})(2)(1972)$ provides that a simple denial will not satisfy the burden.

43. See Bureau of Naval Personnel Manual $\$ 3420250(7)(\mathrm{d}), 32$ C.F.R. $\$ 730.15(\mathrm{~g})(\mathrm{d})$ (1972), MarCorSep Man $\{9$ 6024(7)(f), (g), 32 C.F.R. $\$ \$ 730.73(\mathrm{~g})(6)$, (7) (1972).

44. For an example of similar command influence, see Cole v. United States, 171 Ct. Cl. 178 (1965), where a major general both ordered the Board of Inquiry to convene and presented a prejudicial briefing to the Board in the absence of the accused and his counsel.

45. 32 C.F.R. $\$ 41.3(\mathrm{i})$ (1972). This "official" must be a military commander exercising general court-martial jurisdiction or higher authority when an Undesirable Discharge is to be issued. Id. $\$ 41.7(\mathrm{~d})$. If a General Discharge for Unsuitability is to be issued, the "official" must be a commander with at least special court-martial jurisdiction. $I d . \$ 41.7(\mathrm{c})$.

46. $I d . \S 41.8(\mathrm{~d})(1)$.

47. Id. $\$ 41.8$ (d)(2).

48. Id.

49. Id. $\$ 41.8(d)(6)$. Only the Army and Air Force fail to utilize this authority. See

AR 635-212 I 19(d); AFM 39-12, Table 2-A-1.

50. 32 C.F.R. $\$ \S 41.4(a)(9), 4 I .8(d)(4)(1972)$.

51. Id. $\S 41.8(\mathrm{~d})(5)$.

52. But see p. 68 infra. 
view bodies. The first-level review body, the Discharge Review Board, ${ }^{53}$ may investigate, either on its own motion or on request, the discharge of a former service member at any time during the fifteen years following discharge. It must grant a personal hearing to any former service member who requests one and, in its discretion, may allow witnesses to present evidence either in person or by affidavit. The board is empowered to reclassify a discharge or to issue a new discharge, subject to the review of the Secretary of the service..$^{54}$

Should a former member be denied relief by a Discharge Review Board or should he demand relief-such as reinstatement or a money settlement-which is beyond the power of a Discharge Review Board, he may apply to the Board for the Correction of Military Records (BCMR) of his service for relief. The statute creating these secondlevel review bodies ${ }^{55}$ authorizes the Secretary of each service, acting through civilian employees, to "correct any military record . . . when . . . necessary to correct an error or remove an injustice." 58 BCMR's, in performance of this function, may thus correct erroneously issued discharges. Thereafter the military department is authorized to pay back wages and other pecuniary benefits which become due as a result of the correction and the Secretary of the service may reinstate the former serviceman. ${ }^{57}$

Although the statute allows BCMR intervention before a discharge is issued, the BCMR's generally will not rule on an application until

53. 10 U.S.C. $\$ 1553$ (1970). Each service has established such a body. The implementing regulations of the services are similar. All provide that a Discharge Review Board will consist of five commissioned officers on active duty, that the rules of evidence do not apply, and that no expense for a petitioner's counsel or witnesses will be paid by the Government. They all provide that the board may not revoke any discharge or reinstate any person in the military service. The Army regulation appears at 32 C.F.R. $\$ 581.2$ (1973); the Air Force regulation is at 32 C.F.R. Pt. 865, subpart B (1972); the Navy's appears at 32 C.F.R. Pt. 724 (1972).

54. There has been much controversy concerning the power of the Secretary to deny a board's finding in favor of a petitioner. See note 61 infra.

55. 10 U.S.C. $\$ 1552(1970)$.

56. 10 U.S.C. $\$ 1552$ (a) (1970). It has been argued that the authority thus granted the BCMR's by Congress is unconstitutionally broad. See Harris, Some Principles Governing the Board for the Correction of Naval Records and the Federal Statute Creating It: A Legalistic Approach, 42 GEo. L.J. 210, 239 (1954).

57. 10 U.S.C. $\$ \$ 1552$ (c), (d) (1970). Reinstatement, however, is almost never granted. In the Army it is estimated that "less than one percent of the cases involved direct reinstatement ...." Letter from Executive Secretary, Army Board for the Correction of Military Records, May 11, 1971, on file with the Yale Law Journal. The Air Foree makes the policy more explicit: "[R]einstatement is not generally granted except in instances where the reason for discharge is invalidated and the member has only a short time until retirement." Letter from Executive Secretary, Air Force Board for the Correction of Military Records, May 7, 1971, on file with the Yale Law Journal. The number of cases brought before the Board for the Correction of Naval Records where the petitioner asks for and obtains reinstatement "is very small." Again it is a remedy generally limited to those close to retirement. Letter from Executive Secretary, Board for the Correction of Naval Records, May 10, 1971, on file with the Yale Law Journal. 
the serviceman has been discharged.5s The services' respective regulations provide that all available administrative remedies must be exhausted prior to application for review by a BCMR, ${ }^{59}$ and that, in any event, a BCMR may deny an application without a hearing and without providing a reason for the denial. ${ }^{\circ 0}$ If a hearing is granted, hearing procedures are nearly the same as those of Discharge Review Boards. ${ }^{61}$

\section{Remedial Bases for Judicial Relief}

The available remedial bases for judicial relief from derogatory administrative discharge action are enumerated in $\S 10$ of the Administrative Procedure Act (APA). ${ }^{62}$ Although actions of courts-martial and military commissions ${ }^{63}$ and of military authority exercised in the field in time of war or in occupied territory ${ }^{64}$ are excluded from the scope of the Act, its legislative history ${ }^{65}$ and numerous judicial decisions $^{66}$ indicate that it applies to other military functions, including administrative discharge proceedings. It empowers courts, inter alia, to set aside agency action found to be "contrary to constitutional right,

58. The Board for the Correction of Naval Records makes an exception to this rule in that it will consider an application from an officer whose performance is reported as "unsatisfactory" for promotion purposes under 10 U.S.C. $\$ 6384$ (1970) before his discharge. Letter from Executive Secretary, Board for the Correction of Naval Rccords, March 19, 1971, on file with the Yale Law Journal. Naval enlisted personnel with less than eight years' service who are being processed for General Discharges without a hearing are not given similar rights before the Correction Board.

59. 32 C.F.R. $\$ 581.3(c)(3)$ (1973) (Army); 32 C.F.R. $\$ 865.5$, subpart A (1972) (Air Force); 32 C.F.R. $\$ 723.3$ (c) (I972) (Navy).

60. The courts have held that a denial of a hearing by a BCMR cannot be overturned unless it is clearly shown to be arbitrary or capricious. See, e.g., Kurfess v. United States, 169 Ct. Cl. 486 (1965).

61. See regulations cited in note 53 supra and 32 C.F.R. $\$ 581.3$ (1973) (Army); 32 C.F.R. Pt. 865, subpart A (1972) (Air Force); 32 C.F.R. Pt. 723 (1972) (Navy). As in the case of Discharge Review Board recommendations, the Secretary of the Department may overrule the BCMR's recommendations for relief. It has been held, however, that the Secretary may overrule a BCMR's findings only when they "are not justified by the record." Nelson v. Miller, 373 F.2d 474 (3d Cir.), cert. denied, 387 U.S. 924 (1967); Hertzog v. United States, 167 Ct. Cl. 377, 384-85 (1964); Proper v. United States, 151 F. Supp. 317, 326 (C. Cl. 1957). Whether the Secretary may reach a conclusion contrary to that of a BCMR when the evidence before it was conflicting has not been decided. See Weiss v. United States, 408 F.2d 416, 422 (Ct. Cl. 1969). The Secretary of the Army "seldom" denies relief recommended by the Army Correction Board, Letter, supra note 57; in the Air Force denial is "rare," Letter, supra note 57; in the Navy relief has bcen denied in "about fifty cases" since 1946, Letter, supra note 57.

62. 5 U.S.C. $\$ \$ 701-06(1970)$.

63. Administrative Procedure Act (APA) $\$ 2(a)(2), 5$ U.S.C. $\$$ 701(b)(1)(F) (1970).

64. APA $\$ 2(a)(3), 5$ U.S.C. $\$ 701(b)(1)(G)(1970)$.

65. "Thus, certain war and defense tunctions are exempted, but not the War or Navy Departments in the performance of their other functions." S. REP. No, 752, 79th Cong., 1st Sess. 5 (1945).

66. See Garmon v. Warner, 358 F. Supp. 206, 208 (W.D.N.C. 1973) and cases cited in note 194 infra. 
power, privilege, or immunity," "in excess of statutory jurisdiction, authority, or limitations, or short of statutory right," "without observance of procedure required by law," "unsupported by substantial evidence in a case ... reviewed on the record of an agency hearing provided by statute," or "arbitrary, capricious, an abuse of discretion, or otherwise not in accordance with law." 67

\section{A. The Constitutional Claim: Violation of Due Process}

\section{Givilian Standards}

It seems likely that many administrative discharge procedures would be deemed unconstitutional if judged by due process standards applicable to civilians. Both the Undesirable Discharge and the General Discharge stigmatize the recipient, ${ }^{68}$ yet the regulations governing their issuance do not mandate confrontation and cross-examination of adverse witnesses. ${ }^{69}$

That such procedures, if applied to civilians, would offend due process rights emerges primarily from Greene v. McElroy. ${ }^{70}$ In Greene the Supreme Court set forth, albeit in dicta, due process restrictions on government action resulting in job loss under stigmatizing conditions. Greene, a civilian employee of a defense contractor, was dismissed by his employer after his security clearance was revoked by Defense Department officials. ${ }^{71}$ Afforded a hearing after the revocation and informed by letter that the basis for the revocation was his alleged subversive activities, Greene was neither told the names of persons who had made statements against him nor allowed to view their statements. He had, furthermore, no opportunity to confront witnesses against him at the hearing. As a result of the revocation of

67. APA $\$ \S 10(\mathrm{e})(\mathrm{B})(1-5), 5$ U.S.C. $\$ \S 706(2)$ (A-E) (1970). APA $\S 10(\mathrm{e})(\mathrm{B})(6), 5$ U.S.C. $\$ 706(2)(F)(1970)$, allows a court to overturn administrative fact findings "unwarranted by the facts to the extent that the facts are subject to trial de novo by the reviewing court." This provision, however, generally applies only when such a trial is specifically authorized by statute. See, e.g., Consolo v. Federal Maritime Comm'n, 383 U.S. 607, 619 n.17 (1966). There is no statute giving such a right in judicial review of administrative discharge proceedings.

68. The services freely admit that both create substantial prejudice in civilian life, see pp. 9-10 supra, and a recent empirical study bears this out. See Jones, supra note 8. Although the reason for discharge does not appear on the discharge certificate, such information is not difficult for a potential employer to discover. See Nelson v. Miller, 373 F.2d 474, 477 (3d Cir.), cert. denied, 387 U.S. 924 (1967).

69. See p. 39 supra.

70. 360 U.S. $47 \frac{4}{4}$ (1959). See K. Davis, Administrative Law Treatise $\$ 7.13$, at 347 (1970 Supp.) [hereinafter cited as DAvis (1970 Supp.)].

71. 360 U.S. at 475 . 
his clearance, Greene not only lost his job but was unable to obtain comparable employment elsewhere. ${ }^{72}$

In voiding the withdrawal of Greene's security clearance, the Supreme Court restricted its precise holding to a narrow ground: The Department of Defense was not specifically authorized by statute or executive order to promulgate security clearance regulations "under which affected persons may lose their jobs and may be restrained in following their chosen professions" without allowing the person to confront and cross-examine adverse witnesses. ${ }^{73}$ But the Court went on to criticize the procedure on constitutional grounds, stating, inter alia, that

[w] here governmental action seriously injures an individual, and the reasonableness of the action depends on fact findings, the evidence used to prove the Government's case must be disclosed to the individual so that he has an opportunity to show that it is untrue .... We have formalized these protections in the requirements of confrontation and cross-examination ... . This Court has been zealous to protect these rights from erosion. It has spoken out not only in criminal cases ... but also in all types of cases where administrative and regulatory action were under scrutiny $\ldots . .^{74}$

Since the Court was able to achieve an appropriate result by construing statutes and executive orders, it eschewed a constitutional holding. ${ }^{75}$ The extensive due process analysis provided by Chief Justice Warren nonetheless makes it apparent that the Court was prepared to decide the case on constitutional grounds if a narrower holding had not been available. ${ }^{76}$

This inference is strengthened by subsequent Supreme Court decisions which have established that before government action may effectively deprive an individual of employment in his chosen profes-

72. Id. at $475-76$.

73. Id. at 493. The Court expressed its "concern that traditional forms of fair procedure not be restricted by implication or without the most explicit action by the Nation's lawmakers ...." Id. at 508 .

74. Id. at 496-97; accord, Goldberg v. Kelly, 397 U.S. 254, 270 (1970).

75. 360 U.S. at 508 .

76. See id. at 496-99, 506-08. In a concurring opinion Justice Harlan criticized the majority opinion for dealing "unnecessarily ... with the very [constitutional] issue it disclaims deciding. For present purposes no more need be said than that we should not be drawn into deciding on the constitutionality of the security-clearance revocation procedures employed in this case until the use of such procedures . . has been ... expressly authorized by the Congress or the President ...." Id. at 509 . 
sion, ${ }^{77}$ label him guilty of criminal or quasi-criminal activity, ${ }^{78}$ or deprive him of important statutory benefits, ${ }^{79}$ due process requires that he have an opportunity to cross-examine adverse witnesses. ${ }^{30}$

Since administrative discharges inflict comparable penalties without affording servicemen the rights of confrontation and cross-examination, a court applying civilian due process standards clearly would find administrative discharge procedures constitutionally defective.

This conclusion is unaffected by exceptions and qualifications in due process doctrine which somewhat limit its application in the area of government action impinging on employment opportunities. In Cafeteria \& Restaurant Workers Local 473 v. McElroy, ${ }^{81}$ the Court refused to declare unconstitutional the withdrawal of a security badge from an employee of a military concessionaire, even though forfeiture of the badge entailed job loss. The Court held that the employee had no due process right to disclosure of the reason for the withdrawal or a hearing to refute evidence against her" ${ }^{82}$ on the ground that "this [was] not a case where government action has operated to bestow a badge of disloyalty or infamy, with an attendant foreclosure from other employment opportunity." $\$ 3$

Thus, if derogatory administrative discharges did not have such deleterious effects, a serviceman could not mount a viable due process challenge, since due process does not otherwise limit the government's discretion to dismiss its own employees. ${ }^{84}$ Such discharges, however, are more than simple dismissals: They are actions which create a seri-

77. See Willner v. Committee on Character and Fitness, 373 U.S. 96 (1963) (courtappointed committee controlling admission to state bar).

78. See Jenkins v. Mckeithen, 395 U.S. 411 (1969) (public adjudication of guilt by investigative body); In re Ruffalo, 390 U.S. 544 (1968) (changing basis of charges after disbarment hearing); Reilly v. Pinkus, 338 U.S. 269, 276 (1949) (Post Office order banning delivery of mail to perpetrator of mail fraud).

79. See Goldberg v. Kelly, 397 U.S. $254(1970)$ (welfare benefits). For further discussion of Kelly sec note 120 infra.

80. Id. at 269. See Hannah v. Larche, 363 U.S. 420, 441-42 (1960) (dictum); Bridges v. Wixon, 326 U.S. 135, I52-54 (1945); I.C.C. v. Louisville \& N.R.R., 227 U.S. 88, $93-94$ (1913).

81. 367 U.S. 886 (1961).

82. Id. at 894 .

83. Id. at 898 . But cf. Deoclopments in the Law-The National Security Interest and Civil Liluerties, 85 HARv. L. REv. 1130, $1183-89$ (1972), which argues that an unfavorable loyalty determination by the government may create employment difficulty and stigmatization.

84. 367 U.S. at 896. For an argument that due process ought to protect government cmployees from arbitrary dismissal see Comment, Due Process and Public Employment in Perspeclive: Arbitrany Dismissals of Non-Civil Service Employees, 19 U.C.L.A. L. REv. 1052 (1972). Of course, a government employee may not be dismissed in violation of applicable employment regulations promulgated by the employing agency. See Service v. Dulles, 351 U.S. 363 (1957). 
ous and permanent stigma for recipients ${ }^{85}$ and therefore do not fall within the Cafeteria Workers exception. ${ }^{86}$

\section{Applicability of the Fifth Amendment to Military Administrative Discharge Proceedings}

It is thus hardly surprising that Greene initially appeared to bode well for servicemen's efforts to extend traditional due process protections to administrative discharge proceedings. In Bland $v$. Connally ${ }^{87}$ and Davis v. Stahr, ${ }^{88}$ the first post-Greene decisions to deal with such discharges, the Court of Appeals for the District of Columbia Circuit reviewed administrative discharges given for security reasons. Both discharge actions were based entirely on "confidential" information not disclosed to the person discharged. ${ }^{89}$ The dischargees challenged the right of the services to award them derogatory administrative discharges without adhering to minimum due process standards and sought to have their discharges reclassified as honorable.

The court disposed of both cases on the same narrow basis that the Supreme Court had utilized in Greene. Determining that there had been no express congressional grant of authority to establish facts by secret evidence, the Davis court held that "where the denial of the right of confrontation can be so prejudicial, we think any cancellation of the right must come from Congress and be explicit." ${ }^{\text {" To }}$ Though the derogatory administrative discharges of the two men were thus voided on the ground of insufficient authorization, the court relied heavily on the broad constitutional pronouncement in Greene as the underlying rationale for its action. ${ }^{91}$

Unfortunately, another line of cases has construed Greene less favorably for servicemen's due process challenges to administrative discharge provisions. In Reed $\nu$. Franke ${ }^{92}$ a Navy non-commissioned officer with more than eighteen years of service was alleged to have collided with a Rear Admiral's car while driving under the influence of alcohol. It was ordered that he be given a General Discharge (apparently for alcoholism) without being afforded a predischarge hearing..$^{03}$ Before

85. See, e.g., Bland v. Connally, 293 F.2d 852,858 (D.C. Cir. 1961); pp. $35-36$ supra.

86. The continuing validity of the Cafeteria Workers exception has been cast in doubt

by a recent Fourth Circuit decision, McNeill v. Butz, 480 F.2d 314 (4th Cir. 1973).

87. 293 F.2d 852 (D.C. Cir. 1961).

88. 293 F.2d 860 (D.C. Cir. 1961).

89. Bland v. Connally, 293 F.2d at 854-55; Davis v. Stahr, 293 F.2d at $861,863$.

90. 293 F.2d at 863 . The Bland holding was identical. 293 F.2d at 857 .

91. Bland v. Connally, 293 F.2d at 858-59; Davis v. Stahr, 293 F.2d at 863-64.

92. 297 F.2d 17 (4th Cir. 1961).

93. Under current regulations this is no longer possible for military personnel with Reed's length of service. See pp. 37-38 supra. 
discharge could be executed, he brought suit, claiming that such summary procedures violated his constitutional due process rights. Noting that the Navy regulations under which Reed was discharged had been authorized by the President, ${ }^{94}$ the court distinguished Greene on the ground that the Supreme Court there had "expressly refused to speculate on the constitutionality of the regulations had they been approved by Congress or the President." ${ }^{5}$ The broader due process discussion in Greene was ignored.

The Reed court then argued that, in any event, the Navy provisions complied with the due process clause. This argument was clearly erroneous. The court theorized that Reed could demand a mandatory hearing before the Navy Discharge Review Board. This potential hearing, which could not occur until after discharge, ${ }^{96}$ was said to satisfy due process requirements. ${ }^{97}$ As authority for its due process holding the Reed court cited the Supreme Court's decision in Ewing v. Mytinger \& Casselberry, Inc. ${ }^{98}$ and similar cases preceding it. ${ }^{99}$ But Ewing and the other cases cited stand for the proposition that "no hearing at the preliminary stage is required by due process so long as the requisite hearing is held before the final administrative order becomes effective."100 In Reed's case, however, the discharge would already have been effective by the time he had the opportunity to bring an appeal to the Discharge Review Board.101

The question of what "process" is "due" aside, whatever due process safeguards are required must normally be afforded before an adverse administrative action takes effect. This has become perhaps clearer in the years since Reed, ${ }^{102}$ but the proposition was by no means novel in 1961 when the Fourth Circuit decided the case. ${ }^{103}$ Thus, the Reed

94. All Navy regulations must be approved by the President. 10 U.S.C. $\$ 6011$ (1970). His approval authority has been delegated to the Secretary of Defense pursuant to 3 U.S.C. \$ 301 (1970) by Exec. Order No. 10,62I(I)(a), 3 C.F.R. 259 (1954-58 Compilation), as amended by Exec. Order No. 11,294, 3 C.F.R. 137 (1966 Compilation).

95. 297 F.2d at 26.

96. See p. 41 supra.

97. 297 F.2d at 27 . The line of cases that follow Reed have agreed that as long as a hearing is available at some point in the discharge procedure, even after discharge has physically occurred, due process requirements are satisfied. See, e.g., Wilson v. Secretary of the United States Navy, 417 F.2d 297 (3d Cir. 1969), cert. denied, 397 U.S. 1068 (1970);

Courtney v. Secretary of the Air Force, 267 F. Supp. 305 (C.D. Cal. 1968); Justus v.

Zimny, 250 F. Supp. 719 (N.D. Cal. 1965)

98. 339 U.S. 594 (1950).

99. 297 F.2d at 27, citing Inland Empire Dist. Council v. Millis, 325 U.S. 697, 710

(19.15); Opp Cotton Mills, Inc. v. Administrator of the Wage \& Hour Division, 312 U.S.

126, 152.53 (1941); United States v. Illinois Cent. R.R., 291 U.S. 457, 463 (1934).

100. 339 U.S. at 598. See cases cited note 99 supra.

101. See p. 41 supra.

102. See, e.g., Goldberg v. Kelly, 397 U.S. 254 (1970).

103. See, e.g., cases cited note 99 supra. 
court's misuse of Ewing is perhaps more significant than it appears: Coupled with the court's unwillingness to consider the underlying due process rationale of Greene, ${ }^{104}$ it may well reflect implicit doubt that civilian standards of due process protection extend to servicemen who are administratively discharged..$^{105}$

Such doubt is hardly unfounded. Servicemen have never enjoyed all of the protections of the Fifth Amendment. The Fifth Amendment itself exempts "cases arising in the land or naval forces" from the grand jury indictment requirement. ${ }^{106}$ Early opinions interpreted this language to mean that members of the armed forces were completely beyond the protective ambit of the Fifth Amendment, ${ }^{107}$ but in 1953 the Supreme Court held in Burns v. Wilson ${ }^{108}$ that at a minimum the due process clause of the Fifth Amendment protects military personnel from "crude injustices" and lack of "rudimentary fairness" in courtmartial proceedings. ${ }^{109}$

Burns failed to clarify the degree or type of due process protection enjoyed by servicemen, ${ }^{110}$ and, to this date, the Supreme Court has not expanded or elucidated its Burns holding. Conclusions about the constitutional protection due servicemen must, therefore, remain somewhat tentative. ${ }^{111}$

104. $297 \mathrm{~F} .2 \mathrm{~d}$ at 26. Reed and the cases following it reject by implication the notion that due process in this context requires, at some point at least, a right to confront and cross-examine adverse witnesses, since post-discharge review bodies, lacking subpoena power, do not provide such opportunities to petitioners as a matter of right. See pp. $40-42$ supra.

105. The Reed court did not, however, explicitly differentiate between due process standards applicable to civilians and to servicemen. See 297 F.2d at 27.

106. U.S. Const. amend. V.

107. See, e.g., Johnson v. Eisentrager, 339 U.S. 763, 783 (1950) ("American citizens conscripted into the military service are thereby stripped of their Fifth Amendment rights ...") (dictum); Ex parte Milligan, 71 U.S. (4 Wall.) 2, 138 (1867) (Chase, C.J., concurring).

108. 346 U.S. 137 (1953).

109. Id. at 142 (plurality opinion of Chief Justice Vinson). Justices Reed, Burton and Clark concurred in this formulation. Justice Frankfurter acknowledged that constitutional due process applied but did not delineate its requirement in military trials. Id. at 148. Justices Black and Donglas, in dissent, would have held due process protections fully applicable. Id. at 150 . See Developments in the Law-Federal Habeas Corpus, 83 Harv. L. REv. 1038, 1215-16 (1970), for a discussion of the case.

110. For an analysis of the vagaries of the Burns holding see Bishop, Civilian Judges and Military Justice: Collateral Review of Court-Martial Convictions, 61 CoLUM. L. Rev. $40,51-59$ (1961).

The Court itself has acknowledged a continuing lack of clarity in the area. See, e.g., Reid v. Covert, 354 U.S. 1, 37 (1957). In United States v. Augenblick, 393 U.S. 348 (1969), the Court may have limited the implications of Burns somewhat. There the Court held that a claim based on an alleged violation of the Jencks Act, 18 U.S.C. $\$ 3500$ (1964), which provides that when a witness testifies for the United States, the Government may be required to produce "any statement" of the witness which relates to his testimony, did not rise to a constitutional level and thus did not even arguably justify collateral attack on a court-martial judgment.

111. A jurisdictional impediment has significantly restricted the development in civilian courts of due process standards applicable to servicemen. Most civilian court cases involving servicemen's assertions of due process rights have sought collateral re- 
The Supreme Court's relative silence contrasts with the United States Court of Military Appeals' activism in defining the constitutional rights of those in the military. Created by Congress in $1950^{112}$ with jurisdiction limited to review of serious court-martial convictions, ${ }^{113}$ this Article I court has long taken the position that "the protections in the Bill of Rights, except those which are expressly or by necessary implication inapplicable, are available to members of our armed forces." 114 And in practice the court has ensured that service members involved in court-martial proceedings enjoy nearly all the due process rights accorded civilians. ${ }^{115}$

The due process guarantees enforced by the Court of Military Appeals have of course pertained exclusively to court-martial proceedings. The application of due process safeguards in the administrative discharge context thus requires significant doctrinal extrapolation. To infer that due process limitations on derogatory administrative pro-

view of court-martial judgments. Article 76 of the UCMJ, 10 U.S.C. $\$ 876(1970)$, states that military review of court-martial convictions shall be "final and conclusive" and "binding upon all ... courts ... of the United States." The Supreme Court has long held that, despite this language, the opportunity for collateral attack in civilian federal courts on military judgments by means of habeas corpus remains available. See, e.g., Burns v. Wilson, 346 U.S. 137, I42 (1953); Gusik v. Schilder, 340 U.S. 128, 132-33 (1950). The proper scope of review under the habeas writ and the exclusivity of the jurisdictional basis of the writ for collateral attack remain unclarified issues. See, e.g., Kauffman v. Secretary of the Air Force, 415 F.2d 991 (D.C. Cir. 1969), cert. denied, 396 U.S. 1013 (1970). This jurisdictional difficulty is not relevant in the administrative discharge area, of course, since no court-martial judgment is at stake.

112. 64 Stat. 129 (1950), as amended, 10 U.S.C. \$ 867 (1970).

113. The court must review all convictions which affect general or flag officers, which impose the death penalty, or which are ordered by a Judge Advocate General to be reviewed after previous review by a Court of Military Review. It may grant review on petition of the accused in any case previously reviewed by a Court of Military Review. 10 U.S.C. $\$ 867$ (b) (1970). Court of Military Review jurisdiction extends to the above listed cases plus those involving Bad Conduct or Dishonorable Discharges, officer, cadet or midshipman dismissal, or confinement of one year or more. 10 U.S.C. $\$ 866(\mathrm{~b})$ (1970).

114. United States v. Tempia, 16 U.S.C.M.A. 629, 634, 37 C.M.R. 249, 254 (1967) (Fifth Amendment privilege against self-incrimination), citing United States v. Jacoby, 11 U.S.C.M.A. 428, 430-31, 29 C.M.R. 244, 246-47 (1960) (Sixth Amendment right to confront adverse witnesses); United States v. Richardson, 21 U.S.C.M.A. 54, 44 C.M.R. 108 (1971) (Fifth Amendment prohibition against double jeopardy). Some civilian courts have adopted this formulation as well. See, e.g., Kauffman v. Secretary of the Air Force, 415 F.2d 991, 997 (D.C. Cir. 1969). The Kauffman court explicitly put the burden of proving the necessity for limitation of constitutional rights on the government:

We hold that the test of fairness requires that military rulings on constitutional issues conform to Supreme Court standards, unless it is shown that conditions peculiar to military life require a different rule.

Id.; accord, Avrech v. Secretary of the Navy, 477 F.2d 1237, 1244 (D.C. Cir. 1973).

115. See Sherman, Judicial Review of Military Determinations and the Exhaustion of Remedies Requirement, 55 VA. L. REv. 483, 501 n.102 (1969) (cataloguing the rights guaranteed) and the statement of Judge Quinn of the Court of Military Appeals that "[p]art of our heritage of freedom is the complex of the basic rights embraced within constitutional due process. Those same rights are inseparably interwoven into due process of military law." Quinn, The United States Court of Military Appeals and Military Due Process, 35 ST. Johns L. REv. 225, 254 (1961). See generally Kester, Soldiers Who Insult the President: An Uneasy Look at Article $8 S$ of the Uniform Code of Military Justice, 81 HARv. L. REv. 1697, 1740-43 (1968). 
ceedings are constitutionally required, a court must first conclude that such serious harm may result from the proceedings that protections equivalent to those given in courts-martial are necessary.110 In a recent decision, Crowe v. Clifford, ${ }^{117}$ the Sixth Circuit proved unwilling to take that step. Without dealing with the severity of harm question, the court held that a challenge to a derogatory administrative discharge mounted on the basis of a due process claim ${ }^{118}$ was defective since "principles which govern criminal trials are not applicable to administrative discharge hearings . . . ."119

But the Crowe court's cramped notion of a Fifth Amendment due process clause applicable exclusively to criminal trials is inconsistent with repeated Supreme Court assertions that due process protections cover "not only . . . criminal cases . . . but also . . . all types " of cases where administrative and regulatory action were under scrutiny . . . ."120

Fortunately, underlying doubt that due process safeguards apply to administrative discharge proceedings has not proven uniformly fatal

116. Recent Supreme Court decisions have stressed that due process requirements are triggered by the potential harm which a governmental action may cause. See, e.g., Goldberg v. Kelly, 397 U.S. 254, 262-63 (1970); Joint Anti-Fascist Refugee Comm. v. McGrath, 341 U.S. 123, 163 (1951) (Frankfurter, J., concurring). The government proceeding need not be one which determines criminal culpability in order for duc process guarantees to operate. See, e.g., Greene v. McElroy, 360 U.S. 474, 497 (1959) (dictum) \& note 120 infra.

117. 455 F.2d 945 (6th Cir. 1972).

118. Crowe had been denied the opportunity to confront adverse witnesses or challenge the admissibility of hearsay evidence. Id. at 947 .

119. Id. In support of this statement, the Crowe court cited Brown v. Gamage, 377 F.2d 154 (D.C. Cir. 1967), cert. denied, 389 U.S. 858 (1968). Brown involved an Honorable rather than an Undesirable Discharge and was decided on a theory of waiver of statutory rights to a full and fair hearing. For a discussion severely critical of the reasoning in Brown, see 20 SraN. L. REv. 360 (1968). Other cases in which administrative discharge provisions have been upheld against due process challenges include Wilson v. Secretary of United States Navy, 417 F.2d 297 (3d Cir. 1969), cert. denied, 397 U.S. 1068 (1970); Courtney v. Secretary of the Air Force, 267 F. Supp. 305 (C.D. Cal. 1969); Unglesby v. Zimny, 250 F. Supp. 714 (N.D. Cal. 1965).

120. Greene v. McElroy, 360 U.S. 474, 497 (1959); accord, Goldberg v. Kelly, 397 U.S. 254, $270(1970)$. If the Crowe court was attempting to hold that plaintiff's demand for a constitutional right of confrontation was controlled by the Sixth Amendment, limited by its terms to criminal proceedings, rather than the Fifth Amendment, then the court failed to take adequate cognizance of Goldberg v. Kelly, which established a Fourteenth Amendment due process right to a fair hearing before termination of state welfare benefits. The Court there held that due process required an opportunity at the hearing "to confront or cross-examine adverse witness," id. at 268 . It thus laid to rest any residual doubt that the right of confrontation is not protected under the Fifth Amendment due process clause, as well as under the Sixth Amendment. The inevitable objection that Kelly was decided under the Fourteenth Amendment, while Crowe involved the Fifth Amendment, is easily answered: The Kelly Court itself freely relicd on Fifth Amendment due process decisions requiring confrontation and cross-examination of adverse witnesses as support for its holding that confrontation was required in the welfare termination setting by the Fourteenth Amendment. Id. at 269-70. It thus implied that the coverage of the due process clauses of the Fifth and Fourteenth Amendments is coterminous with respect to rights of confrontation. 
to subsequent assertions of due process claims by recipients of stigmatizing administrative discharges. The Court of Appeals for the District of Columbia Circuit recently held that the Army's extraction of a resignation for the good of the service (resulting in an Undesirable Discharge) from a service member undergoing psychiatric treatment was "indefensible by any acceptable standard of due process and elemental justice"121 and at least one court has applied ordinary courtmartial and criminal court rules to the admissibility of illegally seized evidence in administrative discharge proceedings. ${ }^{122}$

Most active in defining due process rights of service members subjected to administrative discharge proceedings has been the Court of Claims, which has had more experience with military discharge cases than any other court because of its unique authority to award substantial amounts of back pay. ${ }^{123}$ Its decision in Clackum v. United States ${ }^{124}$ invalidated the Undesirable Discharge of an Air Force enlisted woman based solely on information in a "confidential" investigative report on the ground that "it is unthinkable that [the Air Force] should have the raw power, without respect for even the most elementary notions of due process of law, to load her down with penalties." 125 Since Clackum the court has steadily expanded its conception of service members' due process rights. In Middleton $v$. United States, ${ }^{126}$ it held that threatening a court-martial which could not have been brought under Navy regulations in order to induce a Navy enlisted man to resign with an Undesirable Discharge "denied [him] due process and fair treatment." ${ }^{127}$ And in Cole v. United States, ${ }^{128}$ it declared that a discharge recommended by a board of officers after a major general, who was Deputy for Personnel of the Tactical Air Command, had lectured them against showing sympathy violated "plaintiff's rights to that due process protection which the Fifth Amendment extends to military personnel."129

The position of the Court of Claims is clearly preferable to the half-

121. Robinson v. Resor, 469 F.2d 944, 949 (D.C. Cir. 1972). Cf. Hagopian v. Knowlton, 346 F. Supp. 29 (S.D.N.Y. 1972) (due process protections cover West Point cadet in expulsion proceedings).

122. See, e.g., Denton v. Seamans, 315 F. Supp. 279, 285-86 (N.D. Cal. 1970). But cf. Crowe v. Clifford, 455 F.2d 945 (6th Cir. 1972).

123. See pp. 65-66 infra.

124. 296 F.2d 226 (Ct. Cl. 1960).

125. Id. at 228.

126. $170 \mathrm{Ct}$. CI. 36 (1965).

127. Id. at 41 .

128. 171 Ct. Cl. 178 (1965).

129. Id. at 185. But see Grant v. United States, 162 Ct. Cl. 600, 608 (1963) (safeguards of the Fifth and Sixth Amendments "do not come into the picture" in an administrative discharge hearing) (dictum). 
hearted or negative view of the due process rights of servicemen exhibited by other courts. Given the extension of traditional due process rights to servicemen in the court-martial context, it seems proper to afford similar protection in the administrative discharge area. The consequences of an Undesirable Discharge, the most onerous of the administrative dismissals, are nearly identical to those of the Bad Conduct Discharge, which can be awarded only by a court-martial..$^{130}$ The award of a General Discharge likewise creates considerable disadvantage for the recipient $t^{131}$ and thus ought also to be accompanied by due process safeguards, particularly the right to confront and cross-examine adverse witnesses.

\section{Countervailing Governmental Interests}

Even if it is assumed that Fifth Amendment protections extend to the administrative discharge context, a possible impediment for plaintiffs asserting due process claims remains: the presence of countervailing governmental interests. Leading Supreme Court cases developing standards of civilian due process have stressed that in determining the procedural rights due an individual likely to be adversely affected by governmental action, a court must weigh not only the seriousness of the harm but also the countervailing government interest. ${ }^{132}$

Military authorities argue that administrative discharges serve two distinct functions. First, they allow the efficient expulsion of both "troublemakers" whose presence threatens military discipline and service members whose performance does not measure up to minimum standards. ${ }^{133}$ This interest in efficient discharge of the "unfit" would, of course, be adequately served by a system which did not affix stigmatizing labels to persons so discharged..$^{134}$

Second, the military argues that administrative discharges, by characterizing the service rendered, encourage proper behavior. The use

130. See notes 13 \& 14 supra.

131. See p. 35 supra.

132. In Goldberg v. Kelly, 397 U.S. 254 (1970), for instance, the Court said that "[ $t]$ he extent to which procedural due process must be afforded . . . is influenced by the extent to which [one] may be 'condemned to suffer grievous loss' . . . and depends upon whether the ... interest in avoiding that loss outweighs the governmental interest in summary adjudication." $I d$. at 262-63 (footnotes omitted). See, e.g., Cafeteria \& Restaurant Workers Union v. McElroy, 367 U.S. 886, 895 (1961); Hannah v. Larche, 363 U.S. 420, 440, 442 (1960); Joint Anti-Fascist Refugee Comm. v. McGrath, 341 U.S. 123, 168 (1951) (Frankfurter, J., concurring).

133. Statement of Brig. Gen. William W. Berg, Deputy Ass't Sec'y of Defense (Military Personnel Policy), 1966 Hearings, supra note 17, at $356-60$.

134. See, e.g., Bland v. Connally, 293 F.2d 852, 858 (D.C. Cir. 1961). See also 1966 Hearings, supra note 17 , at 119-22, 130, 209-10. 
of a single label for all administrative discharges, including the Honorable, "diminishes the value of the discharge to the man who has given honorable service. You need a way to characterize the service for what it truly is." 135 It is clear that the military also considers that discharge characterization provides disincentives for the misbehavior of "troublemakers." 136 Resort to the less drastic means of awarding neutral label discharges, while not impinging upon the military's interest in speedy discharges, may conflict with this second interest.

The services' interests in effecting speedy discharges and in providing performance incentives and disincentives must be balanced against individual interests if a proper standard of due process is to be formulated. ${ }^{137}$ Giving due consideration to military interests need not prevent a court from striking a balance which allows confrontation and cross-examination of witnesses by the dischargee. Courts have deemed important government interests insufficient to preclude the right of confrontation in other contexts. ${ }^{138}$ And, significantly, in the specific context of administrative discharges, some courts have required that proceedings conform to normal due process standards, despite clear countervailing military interests. ${ }^{139}$

\section{B. Failure to Follow Statutory or Regulatory Procedures}

Despite the fact that discharge regulations clearly ought to be brought within the strictures of the due process clause, courts have traditionally been unwilling to reach constitutional issues if they are able to achieve an appropriate result by construing statutes or administrative regulations. ${ }^{140}$ Thus a number of successful challenges to derogatory administrative discharges have been decided on the basis of the military's own regulations.

If a service member ordered to receive an administrative discharge

135. See Statement of Maj. Gen. Leo E. Benade, Deputy Ass't Sec'y of Defense (Military Personnel Policy), 1971 Hearings, supra note 19, at 5866. Department of Deiense statistics show, however, that a significant number of servicemen who could have been awarded derogatory administrative discharges on the basis of their conduct while in the service are given Honorable Discharges. See id. at 5868. Thus, in actuality, the characterization of service rendered is often inaccurate.

136. See Department of the Army Pamphlet 635-2, Money in the bank ... an Honorable Discharge (June 30, 1967).

137. See Bland v. Connally, 293 F.2d 852, $857-58$ (D.C. Cir. 1961). See also Ervin, supra note 19 , at 18 .

138. See, e.g., Goldberg v. Kelly, 397 U.S. 254, 265-66 (1970) (state interest in conserving fiscal and administrative resources does not justify delay of evidentiary hearings until after discontinuance of welfare grants). See generally Joint Anti-Fascist Refugee Comm. v. McGrath, 341 U.S. 123, 149-74 (Frankfurter, J., concurring).

139. See p. 51 supra.

140. See, e.g., Greene v. McElroy, 360 U.S. 474 (1959); Harmon v. Brucker, 355 U.S. 579 (1958). 
can prove that the military's failure to follow procedures required by statute or by its own regulations worked to his detriment in discharge proceedings, it is clear that he may obtain a judicial declaration that the discharge is invalid.

Section 10 of the APA codifies this doctrine in its mandate that the courts set aside administrative action taken "in excess of statutory authority"141 or "without observance of procedure required by law."142 The Supreme Court has held "that regulations validly prescribed by a government administrator are binding upon him as well as the citizen, and that this principle holds even when the administrative action under review is discretionary in nature."143 Regulations validly promulgated have the force and effect of law; ${ }^{144}$ thus, action taken by an administrative agency in contravention of its regulations is illegal, giving rise to a right to judicial determination of the validity of the action. ${ }^{145}$ Although closely related to considerations of due process, ${ }^{140}$ the requirement that regulations be followed also developed independently as a "judicially evolved rule of administrative law."147

That the rule applies to decisions by the military is beyond question. Complainants who proved violations of regulatory procedures have received favorable judgments in every reported case in which the validity of a military discharge was challenged on that basis.148

141. APA $\S 10(\mathrm{e})(\mathrm{B})(3), 5$ U.S.C. $\S 706(2)(\mathrm{C})$ (1970). See Harmon v. Brucker, 355 U.S. 579 (1958).

142. APA $\S 10(\mathrm{e})(\mathrm{B})(4), 5$ U.S.C. $\S 706(2)(\mathrm{D})(1970)$.

143. Service v. Dulles, 354 U.S. 363,372 (1957). The rule was first developed in cases involving deportation of aliens. See, e.g., Bridges v. Wixon, 326 U.S. 135, 153 (1945); United States ex rel. Bilokumsky v. Tod, 263 U.S. 149, 155 (I923).

144. See, e.g., Paul v. United States, 371 U.S. 245, 255 (1963) (military procurement regulation); Public Utilities Comm'n of California v. United States, 355 U.S. 534 (1958) (Air Force regulation); Billings v. Truesdell, 321 U.S. 542, 551 (1944) (regulation of War Department).

145. See cases cited notes $143-44$ supra.

146. See, e.g., Antonuk v. United States, 445 F.2d 592, 595 (6th Cir. 1971) ("violation by the military of its own regulations constitutes a violation of an individual's right to due process of law"); cf. Bridges v. Wixon, 326 U.S. 135, 152-53 (1945) (regulations must be followed, in part, because they were "designed as safeguards against essentially unfair procedures").

147. Vitarelli v. Scaton, 359 U.S. 535, 547 (1959) (Frankfurter, J., concurring and dissenting). In Vitarelli the rule was applied to invalidate a government employee's dismissal carried out in violation of relevant regulations. The Court found, though, that the employee could have been summarily dismissed had the regulations not been promulgated. This rule has been held not to apply to action taken in violation of regulations which "were not intended primarily to confer important procedural benefits upon individuals in the face of otherwise unfettered discretion ...." American Farm Lines v. Black Ball Freight Service, 397 U.S. 532, 538 (1970). Discharge regulations, however, clearly do not fall within the exception to the rule.

148. See, e.g., Geiger v. Brown, 419 F.2d 714 (D.C. Cir. 1969); Grimm v. Brown, 291 F. Supp. 1011 (N.D. Cal. 1968), aff'd, 449 F.2d 654 (9th Cir. 1971); Glidden v. United States, 185 Ct. Cl. 515 (1968). Cf. Harmon v. Brucker, 355 U.S. 579 (1958); Friedberg v. Resor, 453 F.2d 935, 938 (2d Cir. 1971) (Army regulations setting forth procedures for investigations affecting rights or status of servicemen must be "substantially observed"); Antonuk v. United States, 445 F.2d 592 (6th Cir. 1971). But see the dissenting opinion 
Thus in Conn $v$. United States, ${ }^{149}$ the Court of Claims voided the issuance of an Undesirable Discharge to a Marine sergeant who allegedly ran over and killed a Haitian civilian while he was driving drunk. The discharge was based solely on unsworn statements of Haitian civilians and the ex parte report of an officer sent to Haiti to investigate the accident. The court invalidated the discharge and awarded Conn back pay after finding that the Navy had failed to follow regulations which accorded a person subjected to a "one officer investigation" certain procedural rights, including the right to crossexamine witnesses against him..$^{150}$

A similar decision is Glidden $v$. United States, ${ }^{151}$ where an airman had been given an Undesirable Discharge for homosexuality. He allegedly had been observed to commit a homosexual act by two unnamed policemen watching through a one-way mirror in a theater men's room. The only evidence introduced against him at his hearing was an investigative report based on their ex parte statements to Air Force investigators. The court construed an Air Force regulation generally applicable to administrative hearings to require in most cases that the Air Force produce witnesses against an individual being processed for administrative discharge: ${ }^{152}$

The right not to be convicted on hearsay, and to confront and cross-examine one's accusers, are basic, and are guaranteed by the Regulations involved, with exceptions not here relevant. ${ }^{153}$

of Mr. Justice Rehnquist in Strait v. Laird, 406 U.S. 341, 354 (1972), suggesting that the requirement that regulations be followed "might not carry over undiminished to the military services ...."

149. 376 F.2d 878 (Ct. Cl. 1967).

150. The services have sought to avoid the impact of such judgments concerning investigatory bodies. The Navy responded to Conn, for example, by changing the regulation. Compare 26 Fed. Reg. 11779 (1961) ("A party [to an investigation entitled to cross-examine adverse witnesses] is a person subject to the Uniform Code of Military Justice... whose conduct or performance of duty is "subject to inquiry" "), with 32 C.F.R. $\$ 719.301$ (a) (1972) ("A 'party' is an individual who has properly been designated as such in connection with a court of inquiry or a formal fact-finding body'). The same sort of administrative counterattack occurred as a result of Geiger v. Brown, 419 F.2d 714 (D.C. Cir. 1969), where the Court of Appeals for the District of Columbia Circuit found that the Air Force Personnel Board was an investigative board governed by a regulation giving procedural rights to those appearing before such bodies (AFR 11-1), where "there is no explicit exception thereto," and that the procedures required by the regulations had not been followed. Contra, Keef v. United States, $185 \mathrm{Ct}$. Cl. 454, 469 (1968). After the decision in Geiger the Air Force issued AFR 21-10, Secretary of the Air Force Personnel Counsel (1970), which created such an "explicit exception." Id. I 10 .

151. 185 Ct. Cl. 515 (1968).

152. The regulation was AFR 11-1. See note 37 supra. The court has, however, allowed the Air Force to introduce an affidavit over objection for the purpose of corroborating an undenied confession. See Waller v. United States, 461 F.2d 1273 (Ct. Gl. 1972).

153. $185 \mathrm{Ct}$. $\mathrm{Cl}$. at 521 . To the claim that the police officers were confidential informants the court replied that "[p]rocedural regulations to protect confidential informants cannot be invoked to shield from confrontation and cross-examination material witnesses not properly so classed." Id. at 523. 
Glidden's discharge was declared invalid and he was awarded back pay. ${ }^{154}$

\section{Evidentiary Standards}

Two other bases for challenging derogatory administrative discharge action are contained in the evidentiary standards provided in $\S 10$ of the APA which require courts to set aside agency action found to be "arbitrary, capricious, an abuse of discretion, or otherwise not in accordance with law" or "unsupported by substantial evidence in a case ... reviewed on the record of an agency hearing provided by statute." 155

The two standards thus set forth are not coextensive. While "[i]n all cases agency action must be set aside if the action is 'arbitrary, capricious, [or] an abuse of discretion' . . . ,"156 agency action under the APA can be set aside on the basis of the stricter "substantial evidence" test only when the test's requirements are found not satisfied in judicial review of the record of an agency hearing "provided by statute." 157 In the administrative discharge context the only pre-discharge hearings provided for by statute are those for certain Army and Air Force officers. ${ }^{158}$ Although post-discharge review of administrative discharge action is available through statutory Discharge Review Boards ${ }^{159}$ and Boards for the Correction of Military Records, ${ }^{160}$ only the Discharge Review Board statute makes provision for hearings. ${ }^{101}$ Thus it is doubtful that the substantial evidence test set forth in $\S 10$ of the APA is applicable except in cases involving such Army or Air Force officers or those in which a Discharge Review Board hearing has taken place before judicial review was sought.. ${ }^{162}$

The Army, however, requires by regulation that the fact findings of hearings before boards of officers of the type allowed or required by regulation in derogatory administrative discharge proceedings "must be supported by substantial evidence."163 Moreover, the overwhelming

154. Id. at 528. For a similar decision based on Naval regulations, see Cason v. United States, 471 F.2d 1225, $1231-32$ (Ct. Cl. 1973).

155. APA $\S \S 10(\mathrm{e})(\mathrm{B})(\mathrm{l}),(5), 5$ U.S.C. $\$ \S 706(2)(\mathrm{A}),(\mathrm{E})(1970)$.

156. Citizens to Preserve Overton Park v. Volpe, 401 U.S. 402, 413-14 (1971).

157. APA $\S 10(\mathrm{e})(\mathrm{B})(5), 5$ U.S.C. $\$ 706(2)(\mathrm{E})(1970)$.

158. See, e.g., 10 U.S.C. $\$ \$ 3782(\mathrm{~b}), 3792(\mathrm{~b})$ (1970) (Army); 10 U.S.C. $\$ \$ 8782(\mathrm{~b}), 8792(\mathrm{~b})$

(1970) (Air Force).

159. 10 U.S.C. $\$ 1553$ (1970). For a more detailed discussion see p. 41 supra.

160. 10 U.S.C. $\$ 1552(1970)$. For a more detailed discussion see pp. $41-42$ supra.

161. 10 U.S.C. $\$ 1553$ (c) (1970).

162. Because the Discharge Review Boards have limited remedial powers, see p. 41 supra, they are often passed over by claimants.

163. AR 15-6, Procedures for Investigating Officers and Boards of Officers Conducting Investigations $\uparrow 20$ (current through Change 1 of December 4,1970 ). 
majority of courts reviewing military administrative determinations affecting status of personnel, not only with regard to discharge but also with regard to pay and other matters, have demonstrated no inclination to respect the APA's restriction on the applicability of the substantial evidence test. ${ }^{16 t}$ Despite some wavering, ${ }^{105}$ the Court of Claims seems to be of the view that military administrative action subject to its review must be supported by substantial evidence ${ }^{166}$ and has applied this rule without regard to whether an administrative hearing provided by statute had been held. ${ }^{107}$ Other courts reviewing military administrative action have similarly employed the substantial evidence test without regard for technicalities of the APA. ${ }^{168}$

Although the substantial evidence test has thus been the evidentiary standard most often invoked by courts passing upon the validity of military administrative action, its applicability would be restricted if courts adopt a strict construction of $\S 10$ of the APA. It is therefore important to determine not only when administrative action fails to satisfy the substantial evidence test but also when it may be successfully challenged as arbitrary and capricious.

In applying either standard a court must limit its consideration to the administrative record" 169 and must "review the whole record or those parts cited by a party."170 At this point the two standards diverge. The Supreme Court has held that in determining whether an administrative action was arbitrary, capricious, or an abuse of discretion ${ }^{171}$

164. The only "military" case recognizing the limitation discovered is Krawez v. Stans, 306 F. Supp. 1230, 1234 (E.D.N.Y. 1969), where the court stated in dicta that the substantial evidence rule of $\$ 10$ did not apply to a nonstatutory hearing which led to the dismissal of two cadets from the Merchant Marine Academy.

165. See, e.g., Muldonian v. United States, 432 F.2d 443 (Ct. Cl. 1970); Woodford v. United States, $138 \mathrm{Ct}$. Cl. 228, cert. denied, 355 U.S. 861 (1957); Wales v. United States, 130 F. Supp. 900 (Ct. Cl. 1955).

166. See, e.g., Unterberg v. United States, 412 F.2d 1341, 1346 (Ct. Cl. 1969) (retirement pay); Stephens v. United States, 358 F.2d 951, 955 (Ct. Cl. 1966) (same); Neal v. United States, $177 \mathrm{Ct}$. Cl. 937, 946 (1966) (administrative discharge), and other cases cited in these decisions.

167. See, e.g., Hoffman v. United States, I75 Ct. Cl. 457 (1966) (retirement pay); Merson v. United States, $173 \mathrm{Ct}$. Cl. 92 (1965) (same).

168. See, e.g., Padua v. United States, 463 F.2d 245, 246 n.1 (9th Cir. 1972); Sanford v. United States, 399 F.2d 693 (9th Cir. 1968); Amato v. Chafee, 337 F. Supp. 1214, 1217 (D.D.C. 1972) (administrative discharge); Denton v. Seamans, 315 F. Supp. 279 (N.D. Cal. 1970) (administrative discharge); Lima v. Secretary of the United States Army, 314 F. Supp. 337 (E.D. Pa. 1970) (punitive discharge); cf. Hoorwitz v. Resor, 329 F. Supp. 1050, 1051 (D. Conn. 1970), aff'd mem., 445 F.2d 1407 (2d Cir. 1971).

169. United States v. Carlo Bianchi \& Co., 373 U.S. 709, 715 (1963) (general rule); Grimm v. Brown, 291 F. Supp. 1011, 1014-15 (N.D. Cal. 1968), aff'd, 449 F.2d 654 (9th Cir. 1971) (administrative discharge); $c f$. Ragoni v. United States, 424 F.2d 261, 263 (3d Cir. 1970) (punitive discharge).

170. APA $\S 10(e), 5$ U.S.C. $\$ 706$ (1970). This requirement applies to all standards for review of administrative action set forth in $\$ 10$.

171. Although separately set out, the three words have been assumed by commentators to describe only one standard of review. See, e.g., Berger, Administrative Arbitrariness-A Reply to Professor Davis, 114 U. PA. L. REv. 783, 787 (1966). 
a court "must consider whether the decision is based on a consideration of the relevant factors and whether there has been a clear error of judgment."172 Some courts have stated that the standard is violated only when there is no evidence in the administrative record in support of a fact finding. ${ }^{173}$ Whether or not the latter formulation is accurate, it is undeniable that most military administrative decisions that have been found to be arbitrary have been supported by very little evidence. ${ }^{174}$

Substantial evidence, on the other hand, is defined more expansively as "such relevant evidence as a reasonable mind might accept as adequate to support a conclusion." 175 In deciding whether evidence in the administrative record is sufficient to support an administrative conclusion a court must "take into account whatever in the record fairly detracts" from it. ${ }^{176}$ Although the substantial evidence test thus requires a more thorough and less restricted judicial review of findings and conclusions appearing in an administrative record than does the arbitrary or capricious test, it still falls far short of requiring such protections as due process demands in the context of derogatory administrative discharge proceedings. It does not require a court to set aside administrative findings supported only by hearsay testimony, even when contradicted by "live" witnesses, so long as the reviewing court is satisfied of the underlying validity and probative value of the hearsay evidence relied upon by the agency. ${ }^{177}$

\section{Reviewability, Subject Matter Jurisdiction, and Appropriate Time for Review}

Despite the availability of the remedial bases for review enumerated in the APA, it does not follow that judicial relief will necessarily be available to correct violations of servicemen's substantive rights. Juris-

172. Citizens to Preserve Overton Park v. Volpe, 401 U.S. 402, 416 (1971).

173. See, e.g., Bicknell v. United States, 422 F.2d 1055, 1057 (5th Cir. 1970) and Carlisle Paper Box Co. v. N.L.R.B., 398 F.2d 1, 6 (3d Cir. 1968), both defining arbitrary and capricious action as that having no rational basis in fact.

174. See, e.g., Duhon v. United States, 461 F.2d 1278, 1280 (1972); Egan v. United States, 158 F. Supp, 377, 378 (Ct. Cl. 1958).

175. Consolidated Edison Co. v. N.L.R.B., 305 U.S. 197, 229 (1938). The formulation has often been repeated, most recently in Richardson v. Perales, 402 U.S. 389, 401 (1971).

176. Universal Camera Corp. v. N.L.R.B., 340 U.S. 474, 488 (1951).

177. Richardson v. Perales, 402 U.S. 389,410 (1971). The case is discussed in The Supreme Court, 1970 Terin, 85 HARv. L. REv. 37, 326-34 (1971). A confession obtaincd by law enforcement officials without legally required warnings and other evidence normally suppressed in judicial proceedings by operation of the exclusionary rule, such as the fruits of an illegal search, of course face no impediment to their admission in administrative discharge proceedings in the substantial evidence rule, since their exclusion in judicial proceedings is based not on their lack of reliability or probative value, but upon independent considerations. See Lego v. Twomey, 404 U.S. 477, 488 (1972). 
dictional and timeliness problems constitute potential barriers to judicial enforcement of these rights. ${ }^{178}$

\section{A. Reviewability}

While in an early decision, Reaves $v$. Ainsworth, ${ }^{179}$ the Supreme Court took the position that courts had "no power to review" administrative discharge decisions by the services, ${ }^{180}$ in 1958 the Court clearly established that federal courts do indeed have such power. In that year it decided Harmon $v$. Brucker, ${ }^{181}$ which involved an Army reservist on inactive status who had received an Undesirable Discharge (later changed administratively to a General Discharge) because of pre-induction "subversive" activities. Harmon alleged, inter alia, that Army regulations allowing consideration of pre-service activities in determining the type of discharge to be issued were void as beyond statutory authority. ${ }^{182}$

Both the district court and the court of appeals denied relief on the ground of lack of subject matter jurisdiction. ${ }^{183}$ The Supreme Court reversed, holding that

[t]he District Court had not only jurisdiction to determine its jurisdiction, but also the power to construe the statutes involved to determine whether the respondent did exceed his powers. If he did so judicial relief from this illegality would be available. ${ }^{184}$

178. The existence of a substantive federal right does not imply that federal courts will have original jurisdiction to enforce that right. If violation of a federal statutory right were alleged, for instance, but the amount in controversy fell below $\$ 10,000$, then a federal district court would not have jurisdiction to entertain the suit unless a special jurisdictional grant applied. See 28 U.S.C. $\$ 1331$ (1970); 1 J. MoOrE, FederAL PrACtICE If 0.90 [1] (1972). Such a plaintiff could normally sue to enforce the federal right in a state court. See id. 0.1 . But in the military administrative discharge context, state court relief would probably not be available. See note 185 infra.

179. 219 U.S. 296 (1911).

180. Id. at 304-06. In Reaves an officer sought a writ of certiorari to review an Honorable Discharge for medical unfitness based upon the decision of an examination board. In a phrase much quoted since, the Court held:

To those in the military or naval service of the United States the military law is due process. The decision, therefore, of a military tribunal acting within the scope of its lawful powers cannot be reviewed or set aside by the courts .... The courts have no power to review. The courts are not the only instrumentalities of govId. ernment. They cannot command or regulate the Army.

181. 355 U.S. 579 (1958). For an intelligent survey of the state of the law on the eve of Harmon see Jones, Jurisdiction of the Federal Courts to Review the Character of Military Administrative Discharges, 57 Colum. L. REv. 917 (1957). Successful suits by former service members for back pay or other money alleged illegally withheld as a result of administrative discharge had been maintained before Harmon, however. See, c.g., United States v. Kingsley, I38 U.S. 87 (1891); Egan v. United States, 158 F. Supp. 377 (Ct. Cl. 1958); Carlin v. United States, 100 F. Supp. 451 (Ct. Cl. 1951).

182. Plaintiff's Complaint, allegations 12-16.

183. 137 F. Supp. 475 (D.D.C. 1956), aff'd, 243 F.2d 613 (D.C. Cir. 1957), rev'd, 355 U.S. 579 (1958).

184. 355 U.S. at 582. It seems clear that the same holding on the statutory issue could not be made today. The discharge review board statute has been amended to allow 
While Harmon thus resolves the basic question of judicial power to review derogatory administrative discharges, it does not reveal the full range of jurisdictional bases upon which review may take place.

\section{B. Jurisdictional Bases for Judicial Review}

Before determining upon what basis to claim the jurisdiction of the court, a plaintiff must first decide what type of relief he wishes. The jurisdictional bases available to the serviceman seeking reinstatement in the service or discharge reclassification differ from those which may be used when monetary relief is sought.

\section{Nonmonetary Relief}

A service member desiring reinstatement or a reclassification of his discharge may bring suit only in a federal district court. ${ }^{18 \tilde{s}}$ Subject matter jurisdiction in such a case might be alleged on the basis of any of three statutory provisions: Section 10 of the APA, ${ }^{180}$ the general federal question jurisdictional grant, ${ }^{187}$ or the jurisdictional provision for mandamus actions against federal officers. ${ }^{188}$

A common tactic in administrative discharge cases has been to seek jurisdiction under $\S 10$ of the APA and judicial relief under the Declaratory Judgment Act. ${ }^{159}$ Of these two acts, only $\S 10$ of the APA can be construed as a grant of subject matter jurisdiction. ${ }^{190}$ Section

review "based on the records of the armed forces concerned and such other evidence as may be presented to the board." 10 U.S.C. $\$ 1553$ (c) (1970) (emphasis added); cf. Stapp v. Resor, 314 F. Supp. 475, 479 (S.D.N.Y. 1970). Harmon's jurisdictional holding is, of course, unaffected by the statutory change.

185. It is doubtful that state courts have authority to render such relief. See Cortright v. Resor, 325 F. Supp. 797, 810 (S.D.N.Y.), rev'd on other grounds, 447 F.2d 245 (2d Cir. 197I), cert. denied sub nom. Cortright v. Froehlke, 405 U.S. 965 (1972).

186. 5 U.S.C. $\$ 701$ et seq. (1970).

187. 28 U.S.C. $\$ 1331(1970)$.

188. 28 U.S.C. $\$ 1361$ (1970). A fourth possible basis for jurisdiction once existed. Until recently the District Court for the District of Columbia had subject matter jurisdiction of all civil actions brought by or against a resident of the District of Columbia in addition to the jurisdiction given by the statutes set out above, a provision which was often used to sue government officers. See, e.g., Stark v. Wickard, 321 U.S. 288, 290 (1944); Peoples v. United States Dep't of Agriculture, 427 F.2d 561, 564 (D.C. Cir. 1970). This provision may have been the basis of subject matter jurisdiction in Harmon $v$. Brucker, which was brought in the District of Columbia. But see Comment, Judicial Review of Army Discharge Procedures, 9 Sran. L. Rev. 170, $175-79$ (1956), which ad. vances 28 U.S.C. $\$ 1331$ as the jurisdictional basis in Harmon. The unique subject matter jurisdiction of the District of Columbia district courts has been removed, howcver, except as to actions commenced before Feb. 1, 1971 (or before Aug. 1, 1973, where the amount in controversy exceeds $\$ 50,000)$, eliminating its future usefulness as a jurisdictional basis for revicw of administrative action. D.C. Code Ann. $\$ \$ 11-501$ (1), (4) (Supp. V, 1972). See Common Cause v. Democratic National Comm., 393 F. Supp. 803, 807 n.6 (D.D.C. 1971); H. HART \& H. Wechsler, The Federal Courts and the Federal SYSTEM 1162 (2d ed. 1973).

189. 28 U.S.C. $\$ \$ 2201-02$ (1970).

190. The Supreme Court has clearly held that Congress, in the Declaratory Judgment $\lambda c t$, "enlarged the range of remedies available in the federal courts but did not extend their jurisdiction." Skelly Oil Co. v. Phillips Co., 339 U.S. 667, 671 (1950). 
10 provides that "a person suffering legal wrong because of agency action ... is entitled to judicial review thereof." 191 Though there has been some question whether $\S 10$ is an independent grant of jurisdiction, ${ }^{192}$ the balance of authority holds that it is ${ }^{193}$ and courts reviewing administrative discharges have often asserted jurisdiction under it. ${ }^{194}$

The Supreme Court, however, has not explicitly held that $\S 10$ of the APA is a jurisdictional grant. In Rusk v. Cort ${ }^{195}$ it noted that the district court had relied upon the Declaratory Judgment Act and the APA "[i]n support of its jurisdiction" 196 to review a final administrative determination by the Secretary of State. The Court stated cryptically that "[o]n their face the provisions of these statutes appear clearly to permit an action such as was brought here . . ." 197 No other basis of subject matter jurisdiction was suggested by the Court, nor was the district court's reliance on the APA criticized. Reading Rusk, the Second Circuit has concluded that "the Supreme Court apparently assumed" that $\S 10$ of the APA was jurisdictional. ${ }^{108}$

Some lower courts, however, have interpreted $\S 10^{\circ}$ of the APA to be purely remedial and not jurisdictional. ${ }^{199}$ In Reed $v$. Franke, ${ }^{200}$ the only case involving administrative discharge in which jurisdiction un-

191. APA $\$ 10(a), 5$ U.S.C. $\$ 702$ (1970). Section 10 of the APA also states that a "proceeding for judicial review ... including actions for declaratory judgments or writs of prohibitory or mandatory injunction" may be brought under it. APA $\S 10(\mathrm{~b}), 5$ U.S.C. $\$ 703(1970)$.

192. See cases cited note 199 infra.

193. See, e.g., State Highway Comm'n of Mo. v. Volpe, 479 F.2d 1099, 1105 n.7 (8th Cir. 1973) (dictum); L. JafFe, Judicial Control of Administrative Action 164-65 (1965) [hereinafter cited as JAFFE]; Byse \& Fiocca, Section 1361 of the Mandamus and Venue Act of 1962 and "Nonstatutory" Judicial Review of Federal Administrative Action, 81 HARv. L. REv. 308, 326-31 (1967).

194. See, e.g., Carter v. Seamans, 411 F.2d 767 (5th Cir. 1969) (dictum), cert. denied, 397 U.S. 941 (1970); Nelson v. Miller, 373 F.2d 474 (3d Cir.), cert. denied, 387 U.S. 924 (1967); Scofield v. United States, 297 F. Supp. 1353 (D.P.R. 1969); Crawford v. Davis, 249

F. Supp. 943 (E.D. Pa.), cert. denied, 383 U.S. 921 (1966); cf. Garmon v. Warner, 358

F. Supp. 206, 208 (W.D.N.C. 1973) (wigs for Marine reservists).

195. 369 U.S. 367 (1962).

196. Id. at 371 .

197. Id. at 372 .

198. Toilet Goods Ass'n v. Gardner, 360 F.2d 677, 679 n.1 (2d Cir. 1966), aff'd, 387 U.S. 158 (1967).

199. See, e.g., Arizona State Dep't of Public Welfare v. Department of H.E.W., 449 F.2d 456, 464 (9th Cir. 1971), cert. denied, 405 U.S. 919 (1972); Getty Oil Co. v. Ruckelshaus, 467 F.2d 349, 356 (3d Cir. 1972), cert. denied, 93 S. Ct. 937 (1973). Getty Oil ignored Nelson v. Miller, 373 F.2d 474 (3d Cir.), cert. denied, 387 U.S. 924 (1967), where another panel of the Third Circuit affirmed a district court judgment based solely on $\$ 10$ of the APA as a jurisdictional basis. Arizona State similarly ignored Covington v. Schwartz, 230 F. Supp. 249 (N.D. Cal. 1964), modified and aff'd, 341 F.2d 537 (9th Cir. 1965). See R. Crampton, Report of the Comm. on Judicial Review in Support of Recommendation No. 7 , in 1 Recommendations and Reports of the Administrative CONFERENCE of the United States, January 8, 1968-June 30, 1970, at $177-80$ (n.d.), discussing the courts' response to the question of whether $\$ 10$ of the APA is jurisdictional.

200. 297 F.2d 17 (4th Cir. 1961). 
der $\S 10$ of the APA was found lacking, a Navy non-commissioned officer mounted a constitutional challenge to the administrative procedures by which he was awarded a General Discharge without a hearing. The Court of Appeals for the Fourth Circuit found that the APA did not give it jurisdiction over such an action because the district court was "not called upon [in this instance] . . . to directly review administrative action, as is contemplated by the Act" but rather was to review the constitutionality of the procedure itself. ${ }^{201}$ It thus did not hold that $\$ 10$ of the APA failed to confer any subject matter jurisdiction but only that the Act did not apply under the circumstances.

The second subject matter jurisdictional statute which might be invoked by servicemen seeking reinstatement or reclassification is 28 U.S.C. $§ 1331$, the general federal question jurisdictional grant. ${ }^{202}$ No reported case involving a challenge to administrative discharge, however, has explicitly relied on this statute as a basis for jurisdiction. No doubt the $\$ 10,000$ jurisdictional amount requirement has been an impediment. Yet given the probability of deleterious effects of derogatory administrative discharges on future earning capacity, ${ }^{203}$ surely an allegation that $\$ 10,000$ is "in controversy" would withstand the test for dismissal, i.e., that it appear "to a legal certainty" that the jurisdictional amount is not involved. ${ }^{204}$ Courts have used probable diminution of future earnings in other contexts to satisfy the jurisdictional amount requirement of $\S 1331.205$

The $\$ 10,000$ requirement aside, it seems clear that $\$ 1931$ would provide jurisdiction for challenges to derogatory administrative discharges in which violation of a regulation, a statute, or a constitutional provision were alleged. Whether or not $\S 10$ of the APA is a jurisdictional grant, ${ }^{206}$ it offers a remedial basis for judicial relief in the face of improper agency action. Since the APA is a federal law, a claim

201. Id. at 21 .

202. 28 U.S.C. $\$ 1331$ (a) (1970) gives the district courts "original jurisdiction of all civil actions wherein the matter in controversy exceeds the sum or value of $\$ 10,000$, exclusive of interest and costs, and arises under the Constitution, laws, or treaties of the United States."

203. See pp. 35-36 supra.

204. St. Paul Mercury Indemnity Co. v. Red Cab Co,, 303 U.S. 283, 289 (1938). Indeed, it is now questionable whether courts pay more than purely ritual attention to the jurisdictional amount requirement in such cases. See, e.g., Cortright v. Resor, 325 F. Supp. 797, 808-10 (E.D.N.Y.), rev'd on other grounds, 447 F.2d 245 (2d Cir. 1971), cert. denied, 405 U.S. 965 (1972).

205. See, e.g., Berk v. Laird, 429 F.2d 302, 306 (2d Cir. 1970), cert. denied sub nom. Orlando v. Laird, 401 U.S. 869 (1971). But cf. Boyd v. Clark, 287 F. Supp. 501, 504 (S.D.N.Y.) (dictum), aff'd, 393 U.S. 316 (1968).

206. See p. 61 supra. 
of improper derogatory discharge made under the rubric of $\S 10$ arises "under the ... laws . . . of the United States." 207

The third jurisdictional basis is 28 U.S.G. $\$ 1361$ :

The district court shall have original jurisdiction of any action in the nature of mandamus to compel an officer of the United States or any agency thereof to perform a duty owed to the plaintiff. ${ }^{208}$

This section, however, may be less satisfactory than $\S 10$ of the APA or 28 U.S.C. $\$ 1331$ because of limitations on the type of remedy it envisions. Mandamus has traditionally been available only to "compel the performance, when refused, of a ministerial duty ... [or] to compel action, when refused, in matters involving judgment and discretion, but not to direct the exercise of judgment or discretion in a particular way . . . ."209 The Supreme Court has characterized a ministerial duty as a "duty [which] in a particular situation is so plainly prescribed as to be free from doubt and equivalent to a positive command ...."210

Thus, in order to invoke the mandamus remedy as a means for obtaining review of derogatory administrative discharges, the ex-serviceman must persuade a court that the government has failed to perform a ministerial, or nondiscretionary, duty which is owed him. Keeny $v$. Secretary of the Army ${ }^{211}$ illustrates the limitations of this remedy. Keeny sought a writ of mandamus to require the Army Board for Correction of Military Records and the Secretary of the Army to reconsider his request that his discharge be changed from Undesirable to Honorable. The court denied mandamus relief on the ground that "reconsideration by the Board is clearly a matter of discretion with the Board and the Secretary of the Army."212

"Clear legal duty" or "plain duty" is another formulation of the ministerial and nondiscretionary type of duty which must be owed to the plaintiff before a court will grant mandamus relief. ${ }^{213}$ Two decisions in a context closely related to administrative discharge have interpreted the "clear legal duty" requirement to include failure to

207. 28 U.S.C. $\$ 1331$ (1970).

208. 28 U.S.C. \$ 1361 (1970).

209. Wilbur v. United States ex rel. Kadrie, 281 U.S. 206, 218 (1930). A detailed analysis and critique of the standards of review applied in mandamus actions appears in

K. DAvis, ADMINISTRATIVE LAW TREATISE $\$ 23.11$ (1958) [hereinafter cited as Davis (1958)].

210. Wilbur v. United States ex rel. Kadrie, 281 U.S. 206, 218 (1930).

211. 437 F.2d 1151 (8th Cir. 1971).

212. Id. at 1152. After failing to obtain mandamus relief Keeny unsuccessfully sought review under the improbable jurisdictional basis of habeas corpus. Keeny v. Secretary of the Army, 336 F. Supp. 32 (W.D. Mo. 1971).

213. See JAFFe, supra note 193 , at 181 . 
reclassify a punitive discharge which was awarded in a manner violative of due process. In Ashe $v$. McNamara ${ }^{214}$ the court held that an ex-serviceman could compel the Board of Correction of Naval Records to consider and grant a request to reclassify a Dishonorable Discharge because the discharge was awarded by a court-martial proceeding lacking due process of law. ${ }^{215}$ The court found the "plain duty" requirement satisfied since "it was ... the duty of the Secretary and the Correction Board . . . to treat as void a sentence thus unconstitutionally imposed."'216 In Smith v. McNamara ${ }^{217}$ the Tenth Circuit reiterated the Ashe court's holding that the duty of the service Secretary and the Correction Board to reclassify an unconstitutionally awarded punitive discharge was enforceable by an action in the nature of mandamus under $\$ 1361^{21 s}$ but deemed the court-martial proceeding leading to the discharge free from constitutional defect. ${ }^{210}$

While these decisions are not the only indications of a trend toward liberalization of mandamus standards, ${ }^{220}$ it is nonetheless true, as Professor Davis concluded in 1970, that "authority for moving away from the mandamus tradition under $\$ 1361$ is scanty and unsatisfactory." 221 Thus reliance on $\S 1361$ for jurisdiction in an administrative discharge challenge is hazardous unless the relief sought is performance of a manifestly nondiscretionary duty. ${ }^{222}$ Whether courts will extend the doctrine of $A$ she and Smith to the administrative discharge area, allowing servicemen derogatorily discharged pursuant to unconstitu-

214. 355 F.2d 277 (1st Cir. 1965). Ashe is discussed in Davis (1970 Supp.), supra note $70, \$ 23.10$, at 806 .

215. 355 F.2d at 282 .

216. Id.

217. 395 F.2d 896 (10th Cir. 1968), cert. denied sub nom. Smith v. Laird, 394 U.S. 934 (1969).

218. $395 \mathrm{~F} .2 \mathrm{~d}$ at 899 .

219. Id. at 900 .

220. See, e.g., Peoples v. United States Dep't of Agriculture, 427 F.2d 561 (D.C. Cir. 1970), where the court stated that $\$ 1361$

was intended to permit District Courts generally to issue appropriate corrective orders where Federal officials are not acting within the zone of their permissible discretion or otherwise acting contrary to law, and hence to entertain a civil action under $\$ 10$ of the Administrative Procedure Act.

Id. at 565 (emphasis added). But see Jarrett v. Rcsor, 426 F.2d 213 (9th Cir. 1970); Rural Electrification Administration v. Northern States Power Co., 373 F.2d 686 (8th Cir.), cert. denied, 387 U.S. 945 (1967); Prairic Band of Potawatomie Tribe of Indians v. Udall, 355 F.2d 364 (10th Cir.), cert. denied, 385 U.S. 831 (1966). The Supreme Court left open the question of scope of review under $\$ 1361$ when presented with it. Tooahnippah v. Hickel, 397 U.S. 598, 604 n.8 (1970).

221. Davis (1970 Supp.), supra note $70, \$ 23.10$, at 806 .

222. Mandamus would clearly be available to compel a hearing before a service's Discharge Review Board, since the hearing is mandatory if requested by a petitioner. See 10 U.S.C. $\$ 1553$ (c) (1970) ("A person who requests a review under this section may appear before the board in person ....."). Mandamus would also be available to compel observance of a procedure required by regulation. See, e.g., Bluth v. Laird, 435 F.2d 1065 (4th Cir. 1970); Feliciano v. Laird, 426 F.2d 424 (2d Cir. 1970). 
tional proceedings to compel discharge reclassification by mandamus, remains doubtful. ${ }^{223}$

\section{Monetary Relief}

Plaintiffs must resort to different jurisdictional bases when monetary relief is the desired remedy. The venerable doctrine of sovereign immunity ${ }^{24}$ forbids unconsented suits against the sovereign where "the judgment sought would expend itself on the public treasury or domain."225

Only two statutes giving the sovereign's consent to be sued are appropriate for maintaining suits for monetary claims against the federal government based on a wrongful administrative discharge. First, the Court of Claims has jurisdiction under 28 U.S.C. $§ 1491$, which allows it "to render judgment upon any claim against the United States founded either upon the Constitution, or any Act of Congress, or any regulation of an executive department . . ."226 The Court of Claims has construed this statute to permit suits for money damages for wrongful discharge from military service. ${ }^{227}$ In 1964 Congress created a second jurisdictional basis for monetary recovery by removing a restriction in 28 U.S.C. $\$ 1346$, which gives district courts original jurisdiction concurrent with the Court of Claims for suits against the

223. The limitations on mandamus relicf may not be confined to actions brought under $\$ 1361$. If, for example, a plaintiff brings an action under $\S 10$ of the APA for mandatory relief, the action may be deemed "in the nature of mandamus," and, if so, the traditional limitations will apply. See DAvis (1970 Supp.), supra note 70, \$23.10, at 807.

224. For commentary critical of this doctrine, see DAvis (1970 Supp.) $\$ \$ 27.00-.10$.

225. Land v. Dollar, 330 U.S. 731, 738 (1947). See Mine Safety Appliance Co. v. Forrestal, 326 U.S. 371,375 (1945), dismissing a complaint on the ground that the sovereign was an indispensable party in an action characterized by the Court as "an indirect effort to collect a debt allegedly owed by the government in a proceeding to which the govcrnment has not consented."

When an ex-serviceman seeks nonmonetary relief he may overcome the sovereign immunity barrier by invoking the blatant fiction that the officer who issued the discharge acted without authority and thus may be sued in his personal capacity. See F. JAMES, Civil Procedure $\$ 9.26$ (1965). But see Davis (1970 Supp.), supra note $70, \$ 27.07$, at 932-33. Perhaps because it is based on an obvious fiction, the courts have not strictly adhered to the requirement that the officer sued be named personally. See, e.g., Smith v. United States Air Force and Secretary of the Air Force, 280 F. Supp. 478, 479 (E.D. Pa. 1968). This fiction will not avail, though, if the discharged service member seeks a money judgment. See, e.g., Land v. Dollar, supra at 738; Mine Safety Appliance Co. v. Forrestal, supra at 375 .

226. 28 U.S.C. $\$ 1491(1970)$.

227. See, e.g., Clackum v. United States, 296 F.2d 226 (Ct. Cl. 1960). The Court of Claims has no equity jurisdiction. United States v. King, 395 U.S. I (1969). Thus, although it can award money judgments, it cannot make an enforceable adjudication of status. However, the court must in effect determine status in order to adjudicate monetary liability. In so doing it looks to $\$ 10$ of the APA to guide its review. See, e.g., Hertzog v. United States, 167 Ct. Cl. 377, $384-85$ (1964). Interesting theoretical problems arising from this limitation are discussed in Meador, Judicial Determinations of Military Status, 72 YALE L.J. 1293, 1295-1312 (1963). 
United States for money. In that year the section was amended to eliminate an exception which had prohibited suits in the district courts by officers or employees of the government to recover money allegedly due them as a result of their employment. ${ }^{228}$ Congress failed, however, to delete another important restriction on jurisdiction under this provision: Jurisdiction remains limited to claims aggregating $\$ 10,000$ or less. ${ }^{29}$ The Court of Claims thus remains the only forum for more substantial money claims against the government.

\section{The Requirements of Finality and Exhaustion of Administrative Remedies}

\section{Finality}

While the propriety of judicial review of improper administrative discharge action has been clear since Harmon $v$. Brucker, ${ }^{230}$ the point at which such review may be obtained has not been adequately defined by the courts. The Supreme Court's 1962 decision in Beard v. Stahr ${ }^{231}$ held that judicial interference with an Army administrative discharge proceeding was premature where the Secretary of the Army had not yet acted on the discharge recommendation. ${ }^{232}$ Thus, servicemen must wait at least until a discharge has been ordered before seeking judicial review.

Beard, however, did not consider whether judicial relief is available after discharge is ordered but before the purely mechanical act of separation from the service is carried out. ${ }^{233}$ An analysis of the relevant provisions of the APA indicates that Beard should be limited to its holding and that physical separation pursuant to a discharge order

228. 28 U.S.C. $\$ 1346(a)(2)$ (1970), was made applicable when the exception was deleted by 78 Stat. 699 (1964). See Carter v. Seamans, 411 F.2d 767, 771-72 (5th Cir. 1969), cert. denied, 397 U.S. 941 (1970).

229. 28 U.S.C. $\$ 1346(a)(2)$ (1970). See Carter v. Seamans, 411 F.2d 767 (5th Cir. 1969).

230. 355 U.S. 579 (1958).

231. 370 U.S. 41 (1962).

232. Id. at 42 . In a cryptic dictum the Supreme Court stated that should Beard be ordered removed by the Secretary, then "adequate procedures for seeking redress" were available. $I d$.

233. A few subsequent decisions have misconstrued Beard to establish the principle that the exhaustion of administrative remedies doctrine deprives a court of primary jurisdiction to review an administrative discharge proceeding until after the discharge has taken place and the ex-serviceman has exhausted his postdischarge remedies. See, e.g., Stanford v. United States, 413 F.2d 1048, 1049 (5th Cir. 1969); cf. McCurdy v. Zuckert, 359 F.2d 491, 495 (5th Cir.), cert. denied sub nom. McCurdy v. Brown, 385 U.S. 903 (1966). But, as the Third Circuit noted in Nelson v. Miller, 373 F.2d $474,479 \&$ n.20 (3d Cir.), cert. denied, 387 U.S. 924 (1967), Beard was dismissed only because "the act complained of was uncertain" since discharge had not yet been ordered. The holding in Beard is clearly restricted to the proposition that a military discharge action is not final for purposes of judicial review until the discharge order has been issued; it does not support an exhaustion requirement. 
should not be an inflexible precondition to judicial review. Section 10 (c) of the APA provides that agency action must be "final" before it may be reviewed. ${ }^{234}$ Although the legislative history of the APA makes it clear that "[f]inal action includes any effective or operative agency action for which there is no other adequate remedy in any court," ${ }_{35}$ the Act clearly does not limit judicial review to agency decisions which have been executed. ${ }^{236}$ Indeed, $\S 10(\mathrm{~d})$ of the APA explicitly provides that a court may "postpone the effective date of any agency action or preserve status or rights pending conclusion of [judicial] review proceedings" 237 in certain circumstances.

The ordering of a discharge ought to be considered "final" action for purposes of the APA. After discharge orders are issued, the services themselves, with one minor exception, ${ }^{238}$ afford no further predischarge appeal opportunities. ${ }^{239}$ The discharge action is complete except for the purely ministerial execution of the discharge order. ${ }^{240}$

From this it follows that courts have jurisdiction under the APA to entertain substantive challenges to discharge actions after discharge orders are issued and that courts may give remedial relief to persons still in service, as well as to those already discharged.

\section{Exhaustion of Administrative Remedies}

That a court has jurisdiction to entertain a substantive challenge to a final order does not guarantee that it will necessarily do so. A

234. 5 U.S.C. $\$ 701(1970)$.

235. H.R. REP. No. 1980, 79th Cong., 2d Sess. 43 (1946) (emphasis added); the House Report also notes by way of contrast that "[a]ction which is automatically stayable on further proceedings involed by a party is not tinal." See APA $\$ 10$ (c), 5 U.S.C. $\$ 704$ (1970).

236. See Cities Service Gas Co. v. F.P.C., 255 F.2d 860, 863 (10th Cir.), cert. denied sul nom. Magnolia Petroleum Co. v. Cities Service Gas Co., 358 U.S. 837 (1958), which held that

"[t] he order of [an] agency is final for purposes of review when it imposes an obligation, denies a right, or fixes some legal relationship as a consummation of the administrative process ....."

This formulation of finality complements the ripeness requirement of APA $\$ 10(a), 5$ U.S.C. $\$ 702$ (1970), which implies that a person must suffer a "legal wrong" as a result of agency action before he may seek judicial review. It has recently been suggested that the less rigorous ripeness doctrine has supplanted, in cases to which it applies, the APA's somewhat more restrictive finality requirement. See Project-Federal Administrative Law Developments-1971, 1972 DUKE L.J. 115, $283-92$ (1972) [hereinafter cited as Duke Project].

237. 5 U.S.C. $\$ 705$ (1970). A showing of threatened irreparable injury is necessary for such postponement. See p. 73 infra.

238. The Navy BCMR will consider an application from an officer whose performance is reported as "unsatisfactory" for promotion purposes before his discharge. Se't note 58 supra.

239. Sce 32 C.F.R. $\$ 41.7$ (1972); pp. $40-42$ supra.

240. See Ogden v. Zuckert, 298 F.2d 312, 315-16 (D.C. Cir. 1961) (BCMR consideration is apart from the administrative process preceding finality, which process culminates in issuance of discharge order). The notion that an action may be "final" even though not yet effectuated is discussed in Duke Project, supra note 236, at 283-92. 
court in its discretion may withhold substantive relief pending exhaustion of administrative remedies. ${ }^{241}$ In the discharge context there are two bodies offering review opportunities-Discharge Review Boards and Boards for the Correction of Military Records (BCMR).242 The case law in this area is somewhat murky, but courts tend to require exhaustion before they will substantively review discharge orders. Requiring exhaustion is questionable, however, in light of recent developments in analogous areas of military law and a reexamination of the irreparable injury doctrine in the exhaustion context.

To satisfy the exhaustion requirement a person already discharged may have to present appeals to both bodies. ${ }^{243}$ For the person who has been ordered discharged but who has not yet been physically separated, the situation is somewhat more complicated. Normally neither body will consider his request for review. ${ }^{244}$ If, however, a court issues a stay of discharge "pending" administrative review, a BCMR will review the discharge before it takes effect. ${ }^{245}$

This outline of the procedural structure of administrative remedies as they relate to predischarge review does not, however, do full justice to the complexities which stem from the exhaustion doctrine. Confronted with the fact that two types of administrative remedies exist after discharge, one of which-review by a BCMR-may become available before discharge if a judicial stay is issued "pending" exhaustion, courts have taken four approaches to requests for predischarge judicial relief.

Some courts have refused to consider undertaking predischarge review and have instead required that a serviceman first suffer discharge and then exhaust all remedies which thereafter become available. ${ }^{240}$

241. See, e.g., United States v. Abilene \& Southern Ry., 265 U.S. 274, 282 (1924) (" $[w]$ hether [the court] should have denied relief until all possible administrative remedies had been exhausted was a matter which called for the exercise of its judicial discretion").

242. See pp. 40-42 supra.

243. Discharge Review Boards have more linited remedial powers than BCMR's and thus may be bypassed if an administrative remedy beyond their competence is sought. See pp. 40-41 supra.

244. See pp. 40-42 supra. But see note 238 supra (Naval officer exception). Dis. charge Review Boards are precluded by statute from conducting predischarge review. See 10 U.S.C. $\$ 1553$ (a) (1970) (board of review shall "review the discharge or dismissal (other than a discharge or dismissal by sentence of a general court-martial) of any former member of an armed force ...") (emphasis added); Schwartz v. Covington, 341 F.2d 537, 538 (9th Cir. 1965). Thus a person still in service cannot be required to exhaust his Discharge Review Board remedies as a prerequisite to predischarge judicial relief.

245. See Schwartz v. Covington, 341 F.2d 537, 538 (9th Cir. 1965); telephone conversation with Raymond J. Williams, Executive Secretary, Army BCMR, June 8, 1973.

246. See, e.g., McCurdy v. Zuckert, 359 F.2d 491 (5th Cir.), cert. denied sub nom. McCurdy v. Brown, 385 U.S. 903 (1966); accord, Stanford v. United States, 413 F.2d 1048 (5th Cir. 1969); Tuggle v. Brown, 362 F.2d 801 (5th Cir.) (per curiam), cert. denied, 
A second approach is illustrated by Nelson $v$. Miller ${ }^{247}$ and Sohm $v$. Fowler, ${ }^{24 s}$ which held that, while a court has jurisdiction to grant predischarge relief, it should not intervene until the serviceman has been discharged and has exhausted all subsequently available remedies, unless "special circumstances" dictate that such relief is warranted..$^{240}$

A third approach was taken by the Ninth Circuit in Schwartz v. Covington. ${ }^{250}$ There the court stayed a discharge order pending predischarge action by a BCMR. ${ }^{251}$ The court did not require that the serviceman suffer the discharge and then exhaust his review opportunities before a Discharge Review Board as a prerequisite to remedial judicial relief. 252

Finally one decision, Ogden $v$. Zuckert, ${ }^{253}$ dispensed with the exhaustion requirement altogether holding that substantive predischarge review was available even though the serviceman had exhausted neither of the two types of remedies. Since the Ogden decision in 1961, however, no court has waived the requirement that a serviceman seeking review of an impending discharge exhaust at least those remedies available before discharge.

While it is somewhat difficult to extract consistent principles from the cases, most courts have required plaintiffs to exhaust all "avail-

385 U.S. 941 (1966); Michaelson v. Herren, 242 F.2d 693 (2d Cir. 1957); Bolger v. Marshall, I93 F.2d 37 (D.C. Cir. 1951); Marshall v. Wyman, 132 F. Supp. 169 (N.D. Cal. 1955). In at least one case, such a withholding of judicial relief was premised on the theory that the existence of postdischarge opportunities deprived the court of primary jurisdiction to grant predischarge relief. See McCurdy v. Zuckert, 359 F.2d 491, 495 (5th Cir. 1966). This jurisdictional qualm seems unwarranted in light of the fact that the judicial doctrine of exhaustion clearly operates merely to give a court discretion to withhold relief and does not deprive it of jurisdiction. See note 241 supra.

247. 373 F.2d 474 (3d Cir.), cert. denied, 387 U.S. 924 (1967).

248. 365 F.2d 915 (D.C. Cir. 1966).

249. Nelson v. Miller, 373 F.2d at 479; Sohm v. Fowler, 365 F.2d at 918. Sohm did not specify what it meant by the term "special circumstances." The Nelson court was more explicit, however, stating that "there are some cases in which postdischarge review may be inadequate by the very fact that the interim between discharge and board action harbors a potential for irreparable harm, notwithstanding possible reinstatement." 373 F.2d at 479 . In such cases, presumably, the Nelson court would consider granting predischarge relief. Despite the "special circumstances" language, both Sohm and Nelson did not in fact afford predischarge relief. The special circumstances restriction in Sohm may be in doubt since a recent case in the U.S. Court of Appeals for the District of Columbia Circuit ignored it in granting a civil service employee a stay of discharge pending administrative review without requiring such a showing. Murray v. Kunzig, 462 F.2d 871 (D.C. Cir. 1972), cert. granted, 93 S. Ct. 1494 (1973).

250. 341 F.2d 537 (9th Cir. 1965), aff'g 230 F. Supp. 249 (N.D. Cal. 1964). See p. 73 infra.

251. 341 F.2d at 539 .

252. Id. at 538. The court stated simply that "[a]pplication for the latter [review before the Army Discharge Review Board] cannot be made under the present posture of the case." Other courts have adopted the Schwartz approach. See Murray v. Kunzig, 462 F.2d 871, $884-85$ (D.C. Cir. 1972), cert. granted, 93 S. Ct. 1494 (1973) (civil service cmployee); Vitelli v. Warden, 247 F. Supp. 993, 995 (S.D. Cal. 1965) (administrativc discharge) (dictum); Lynch, supra note 19 , at 158.

253. 298 F.2d 312 (D.C. Cir. 1961). 
able" administrative remedies. This relatively strict adherence to the exhaustion doctrine may be challenged on two grounds.

First, exhaustion is inappropriate where appeal to the reviewing body would be futile. ${ }^{254}$ Relevant to this argument are several recent cases in which the exhaustion requirement was waived in connection with habeas corpus petitions by service members claiming they should have been discharged as conscientious objectors. Typical is United States ex rel. Brooks $\%$. Clifford ${ }^{255}$ where the Court of Appeals for the Fourth Circuit held that exhaustion was not required where the only issue was whether a claim of entitlement to conscientious objector status was legally justified. Noting that the BCMR's had no expertise in legal matters and that resort to them would result in substantial delay to petitioner, whose claim the court found unquestionably valid, the court concluded that an exhaustion requirement would be inappropriate. ${ }^{256}$

Brooks and the cases following $\mathrm{it}^{257}$ are, of course, distinguishable from administrative discharge cases. There is considerable doubt that Congress intended BCMR's to function as part of the apparatus for reviewing conscientious objector claims, ${ }^{258}$ while it is clear that a primary function of the BCMR's is to review claims arising from derogatory administrative discharges. ${ }^{259}$ Nevertheless, the Brooks line of cases offers a broader rationale that is clearly relevant in the administrative discharge area: the notion that, because the BCMR's have no legal expertise, resort to them for purely legal claims of error should not be required. ${ }^{260}$

The manner in which the two types of review boards evaluate legal issues underscores the futility of requiring exhaustion in such instances. The boards rarely determine legal questions themselves. Instead each board relies almost exclusively on the opinions of its service's Office of the Judge Advocate General. ${ }^{261}$ Such reliance reduces "review" of

254. See JAFFE, supra note 193, at 426-32.

255. 412 F.2d 1137 (4th Cir. 1969).

256. Id. at $1140-41$.

257. See, e.g., Cole v. Laird, 468 F.2d 829, 831 (5th Cir. 1972); Patterson v. Stancliff, 330 F. Supp. 110,113 (D. Vt. 1971) and cases cited therein. Cf. Brcinz v. Commanding Gencral, 439 F.2d 785,786 (9th Cir. 1971).

258. See United States ex rel. Brooks v. Clifford, 412 F.2d at 1139-40.

259. See 40 Or. ATr'Y GeN. 504, 505 (1947).

200. See, e.g., United States ex rel. Brooks v. Clifford, 412 F.2d at 1140 ("the issuc here ... was one of law, i.e., whether the facts sustained the clain of conscientious objection in the light of applicable legal principles. Judicial review would not be aided by the views of the Army Board on this question.").

261. The Army BCMR relies on opinions of the Office of the Judge Advocate General of the Army or the General Counsel of the Army. Letter from Executive Secretary, Army Board for the Correction of Military Records, March 3, 1971, on file with the Yale Law Journal. The Army Discharge Review Board followed the opinion of the 
the legal issue to a futile pro forma exercise. ${ }^{262}$ In almost all instances a Judge Advocate officer will have reviewed the case before discharge and have found it to be legally justified. ${ }^{263} \mathrm{~A}$ second look cannot be expected to be of much help to a petitioner. Thus, if a plaintiff bases his claim for relief on a question of law, he ought not be required to press postdischarge administrative appeals before bringing a court action. ${ }^{204}$ This conclusion is merely a specific application of the general rule that only adequate administrative remedies need be exhausted before judicial relief may be sought. ${ }^{205}$

What issues are "legal" issues in this context is not settled. Several cases have held that challenges based on contentions that an armed service had failed to follow its own regulations in effecting discharge should first be presented to the postdischarge review boards. ${ }^{26 s}$ But

Judge Advocate General "in every case" in which one was given. 1966 Hearings, supra note 17, at 932. "[V]irtually all ... [Air Force BCMR cases] involving military justice questions are referred to [the Judge Advocate General]" and, normally, "the action taken by the Board conforms very closely to that recommended by [the Judge Advocate General]." 1966 Hearings 975. In the Navy "the majority" of legal questions presented to either the Discharge Review Board or the Board for the Correction of Naval Records "are reviewed in light of advisory JAG opinions." Id. at 956. The Air Force Discharge Review Board, which has three "legal advisors" of its own (one not an attorncy), is a possible exception. Resort to the Judge Advocate General of the Air Force "is not used as a general practice." Letter from Chief, Airmen Actions Branch, Directorate of Personnel (Pers) Data Systems, Dep't of the Air Force, March 17, 1971, on file with the Yale Law Jaurnal. For an example of BCMR reliance on a JAG opinion, see Owings v. Secretary of United States Air Force (SAFOS), 447 F.2d 1245, 1251-52 (D.C. Cir. 1971), cert. denied, 406 U.S. 926 (1972).

262. See Weiss v. United States, 408 F.2d 416, 422 (Ct. Cl. 1969), stating that reliance by a Correction Board on the Office of the Judge Advocate General for Iegal advice "would deprive the requirement, that the Secretary act through civilian boards, of all real significance and effect." $C f$. Beaty v. Kenan, 420 F.2d 55 (9th Cir. 1969) (since Secretary of the Army had previously rejected request for transfer to inactive status he was unlikely to follow a contrary recommendation of the Army BCMR and thus exhaustion of administrative remedy was not required ).

263. See, e.g., AFM 39-12 Tf 2-8(d), 2-18(d) and MarCorSep Man, supra note 42, \6027, 32 C.F.R. \$ 730.76 (1972).

264. Even if a Board were to ignore the recommendation of the Office of the Judge Advocate General as to the applicable law, the Secretary could probably simply ignore its advice. The Secretary of a military service, as the ultimate authority who has promulgated the discharge regulations, cannot be expected to rule favorably on a challenge to the legality of the manner in which a discharge was awarded. See generally Girault v. United States, 135 F. Supp. 52I, 526 (Ct. Cl. 1955). He may not, of course, arbitrarily or capriciously ignore facts found by the Board. The Court of Claims has held that the Correction Boards have limited authority to "change legal conclusions imbedded in military records," Oleson v. United States, I72 Ct. Cl. 9, 18 (1965), but it is unlikely that the service Secretary is bound by their legal determinations. Weiss v. United States, 408 F.2d 416, 422 (Ct. Cl. 1969), leaves this question open.

265. JAFFE, supra note 193, at 426. The application of the rule is immensely complex. See Davis (1970 Supp.), supra note 70, $\$$ 20.01-20.04, 20.07-20.08; JAFFe 426-32; Sherman, supra note 19 , at $496 \cdot 505$.

266. See, e.g., Nelson v. Miller, 373 F.2d 474, 480 (3d Cir.), cert. denied, 387 U.S. 924 (1967) (resort to Board for the Correction of Naval Records was required when ruling of Board on issue of regulation violation would moot constitutional issue since "the primary authority for the interpretations of such regulations lies within the Navy's own appellate system"); Sohm v. Fowler, 365 F.2d 915, 918-19 (D.C. Cir. 1966) (officer's claim that forced retirement was based on incorrect facts, that it violated 
even if the "legal issues" category is not deemed to encompass regulatory matters, it surely applies to challenges bottomed on allegations of statutory or constitutional violations. ${ }^{207}$ In such instances exhaustion before a BCMR or a Discharge Review Board should not be required.

If a challenge to a derogatory administrative discharge is brought on the basis of questions of fact, on the other hand, the exhaustion doctrine may be more appropriate, since appeal to postdischarge boards which have greater competence to decide factual questions, would not be futile.

Second, even if a court determines that resort to the review boards would not be futile, it still must consider a second factor in determining whether to require exhaustion: Exhaustion is inappropriate when it would entail unavoidable, irreparable injury to the aggrieved party pending administrative consideration. ${ }^{208}$ There has not been perfect agreement as to what types of discharge inflict irreparable injury. The receipt of an Undesirable Discharge consistently satisfies the injury requirement. ${ }^{269}$ Courts have disagreed, however, about the injury likely to result from a General Discharge. ${ }^{270}$ Nevertheless, the harm associated with receipt of a General Discharge seems clearly irreparable. ${ }^{271}$ The time necessary for exhausting postdischarge administrative review is considerable, ${ }^{272}$ and during this period the exservice member must suffer the stigma of the discharge, an injury for which there can be no real compensation even if he eventually succeeds in having it held invalid. ${ }^{273}$

The conclusion which emerges is that exhaustion ought not be required where a serviceman must suffer the irreparable injury of a derogatory discharge in order to exhaust administrative remedies.

Coast Guard regulations, and that it violated the Constitution must first be presented to Coast Guard Board for the Correction of Military Records since regulatory and factual claims might moot constitutional issue and, if not, would "reduce the controverted issue to one of law").

267. Cf. Sohm v. Fowler, 365 F.2d 915, 918-19 (D.C. Cir. 1966).

268. See JAFrE, supra note 193 , at $428-32$.

269. See, e.g., Schwartz v. Covington, 341 F.2d 537, 538 (9th Cir. 1965); Píckell v. Reed, 326 F. Supp. 1086, 1089 (N.D. Cal.), aff'd, 446 F.2d 898 (9th Cir.), cert. denied, 404 U.S. 946 (1971).

270. Crawford v. Davis, 249 F. Supp. 943, 946 (E.D. Pa.), cert. denied, 383 U.S. 921 (1966) and Unglesby v. Zimny, 250 F. Supp. 714 (N.D. Cal. 1964), found irreparable injury in a General Discharge. Contra, McCurdy v. Zuckert, 359 F.2d 491, 491 (5th Cir.), cert. denied sub nom. MicCurdy v. Brown, 385 U.S. 903 (1966).

271. See notes 10 \& 12 supra.

272. The average time for decision of any case by the Army Board for the Correction of Military Records is approximately four months. See United States ex rel. Brooks v. Clifford, 412 F.2d 1137, 1141 (4th Cir. 1969); cf. Nelson v. Miller, 373 F.2d 474, 479 (3d Cir. 1967).

273. Though a BCMR can grant retroactive relief, it obviously cannot adequately compensate for the stigma which the recipient of a derogatory discharge must suffer before the discharge is expunged from his record. See Nelson v. Miller, 373 F.2d 474, 479 (3d Cir. 1967); Schwartz v. Covington, 341 F.2d 537, 538 (9th Cir. 1965). 


\section{Propriety of Stays}

As the previous discussion reveals, the issue of the propriety of stays pending exhaustion arises only where a serviceman challenges an administrative discharge that has been ordered but not yet executed. Rather than granting such a serviceman remedial relief, a court may stay his discharge pending appeal to a BCMR. As noted earlier this body will not normally hear predischarge complaints unless a court grants a stay of discharge pending exhaustion.

In granting stays courts act in their discretion. In a leading 1964 decision, Covington v. Schwartz, ${ }^{274}$ the court isolated four criteria which govern the granting of a stay pending predischarge administrative review: ${ }^{275}$ (1) a demonstrated likelihood that the moving party will prevail on the merits in a district court after exhaustion of administrative remedies; (2) irreparable injury to him if a stay is not granted pending administrative review; (3) no substantial harm to other interested parties (i.e., the military service concerned); and (4) no harm to the public interest. ${ }^{276}$

In administrative discharge cases, the four criteria are not entitled to equal weight. While the relative importance of the first, third and fourth standards remains unclarified in the administrative discharge context, irreparable injury is clearly the crucial criterion. ${ }^{277}$ Both the $\mathrm{APA}^{278}$ and judicial precedent ${ }^{279}$ require that irreparable injury be shown before a stay will issue. As discussed earlier, the award of an Undesirable Discharge has been universally acknowledged to generate irreparable injury and would clearly justify issuing a stay. The proposition that awarding a General Discharge also inflicts irreparable injury and would justify a stay may be somewhat less certain but rests on substantial support.

\section{Conclusion}

This article began with the tale of Private Stapp, a draftee who received an Undesirable Discharge for harboring Marxist beliefs. It ends with a surmise: Had Stapp been fully aware of the jurisdictional and substantive barriers which impede judicial review of derogatory dis-

274. 230 F. Supp. 249 (N.D. Cal. 1964), aff'd, 341 F.2d 537 (9th Cir. 1965).

275. 230 F. Supp. at 252. See Virginia Petroleum Jobbers Ass'n v. F.P.C., 259 F.2d 921 (D.C. Cir. 1958); JAFFE, supra note 193, at 689.

276. 230 F. Supp. at 252.

277. See JAFFE, supra note 193 , at 689 .

278. APA $\$ 10$ (d), 5 U.S.C. $\$ 705$ (1970).

279. See, e.g., Permian Basin Rate Cases, 390 U.S. 747, 773 (1968). 
charge actions, he would never have ventured into court. The doctrinal difficulties which Stapp faced make the "availability" of judicial relief, more often than not, an illusion.

Yet judicial relief is needed. The system by which derogatory administrative discharges are awarded is repugnant to basic notions of fairness. Under it servicemen may be stripped of veterans' benefits and disadvantaged for life without the right to confront and cross-examine witnesses against them. Only by requiring that this system conform to civilian standards of due process can courts insure that the rights of servicemen facing derogatory administrative discharges will be adequately protected. 